\title{
Tax-induced earnings management and book-tax conformity: international evidence from unconsolidated accounts
}

\author{
Sebastian Eichfelder \\ Otto-von-Guericke-University Magdeburg \\ sebastian.eichfelder@ovgu.de \\ Martin Jacob \\ WHU - Otto Beisheim School of Management \\ Martin.Jacob@whu.edu \\ Nadine Kalbitz \\ Otto-von-Guericke-University Magdeburg \\ nadine.kalbitz@ovgu.de \\ Kelly Wentland \\ George Mason University \\ kwentlan@gmu.edu
}

January 2020

\begin{abstract}
We quantify the degree of tax-induced earnings management associated with statutory tax rates and examine whether greater book-tax conformity alters this particular type of earnings management. We first validate a new empirical approach for examining taxinduced earnings management using European unconsolidated financial and ownership information over 2005-2013. We provide robust evidence of significant tax-induced earnings management in both domestic and multinational firms. In particular, the results suggest that a 10 percentage point increase in the corporate tax rate relates to an 8.2 percent decrease in pre-tax book income. We then document that firms in countries with greater book-tax conformity engage in additional tax-induced earnings management. This is important given that it contrasts with prior literature, which does not find an effect for booktax conforming transactions with a change in conformity.
\end{abstract}

Keywords: tax-induced earnings management, book-tax conformity, conforming tax avoidance

JEL Classification: H25, H26, M41

Data Availability: Data are available from the public sources cited in the text.

We are thankful to John Barrick, Kay Blaufus, Rainer Bräutigam, Christina Elschner, Jost Heckemeyer, Margot Howard, Jochen Hundsdoerfer, Kenneth Klassen, Michael Overesch, Ed Maydew, Luisa Prolingheuer, Nadine Riedel, Karim Sadrieh, Maximilian Todtenhaupt, and seminar and conference participants of the $6^{\text {th }}$ Conference of Current Research in Taxation in Bonn 2016, the Workshop on Empirical Tax Research in Mannheim 2016, the $109^{\text {th }}$ Annual Conference on Taxation 2016 in Baltimore, the $4^{\text {th }}$ MaTax Conference in Mannheim 2017, the $15^{\text {th }}$ Arqus Conference in Innsbruck 2019, the Leibniz-Universität Hannover, and the Otto-von-Guericke-Universität Magdeburg for comments, suggestions, and advice. For technical support, we are thankful to Juliane Selle. We also thank Christina Lewellen for insights on booktax conformity measures. All errors are our own. 


\section{INTRODUCTION}

Policymakers and researchers have debated for decades whether accounting values used for assessing taxes should conform with those reported for financial reporting (“book") purposes (Desai 2005; Joint Committee on Taxation 2006). ${ }^{1}$ The argued benefits from greater required conformity between book and tax values are built upon the premise that the opposing incentives for manipulation with each type of reporting will induce more truthful reporting if the values are required to be the same. Thus, firms face a trade-off to either report high book and taxable income (e.g., Erickson, Hanlon, and Maydew 2004) or low income in both accounting systems. Opponents of greater required conformity argue that tax and financial reporting serve very different purposes. Thus, by constraining their values to be the same, greater conformity inhibits these values from serving their distinct objectives. In this study, we contribute to this debate by examining a potential cost with greater book-tax conformity. In particular, we examine whether greater book-tax conformity increases firms' willingness to manipulate consolidated pre-tax book earnings in response to variation in corporate tax rates (typically referred to as conforming tax avoidance or tax-induced earnings management).

Prior literature motivated by this debate has examined the direct effect of book-tax conformity on earnings and their characteristics of earnings (Hanlon, Laplante, and Shevlin 2005; Hanlon, Maydew, Shevlin 2008). By examining how book-tax conformity alters the response of book earnings to variation in statutory tax rates, we consider a second channel for how conformity can influence book earnings. In particular, we analyze how greater conformity alters the influence of an alternative policy (in this case, tax policy) on book earnings. It is important for policymakers to consider not only the direct effects documented

\footnotetext{
${ }^{1}$ A recent example where this debate has resurfaced is with discussions surrounding amendments to Sec. 451 in the Tax Cuts and Jobs Act, which require greater conformity between tax and financial reporting for revenue (Atkinson and Houston 2018).
} 
in prior literature but also these types of indirect consequences with requiring greater conformity.

Another important aspect in motivating our analysis is the implication of book-tax conformity for firm tax avoidance. Prior literature that investigates the influence of booktax conformity on tax avoidance has primarily focused on the implications for nonconforming tax avoidance, whereby companies can access greater tax savings by reporting lower taxable income in a way that does not affect book income (Atwood, Drake, and Myers 2012; Tang 2015). In this study, we alternatively focus on tax-induced management of book earnings, which is indicative of conforming tax avoidance behavior by firms, whereby companies are willing to report lower book income numbers that simultaneously reduce taxable income in order to save taxes. ${ }^{2}$

Separate examination of the effect of book-tax conformity on conforming tax avoidance is important because the prediction for how it affects this type of tax avoidance is ambiguous. On the one hand, greater conformity may increase conforming tax avoidance behavior because it broadens the set of available transactions (i.e., the set of transactions where book and tax treatment conform) and removes nonconforming tax avoidance opportunities as potential substitutes. On the other hand, as shareholders and contracting parties lose information from a second, high-quality (tax) signal about firm performance, they may place even greater weight on the remaining high-quality (book) signal, making it more costly to obtain tax benefits by underreporting book income. Thus, it is unclear ex ante how firms will alter their conforming tax avoidance behavior in response to greater conformity. Existing empirical evidence on this topic is scarce. Chan, Lin, and Mo (2010) analyze how IFRS adoption as one change in book-tax conformity affects tax

\footnotetext{
${ }^{2}$ We use the terms "tax-induced earnings management" and "conforming tax avoidance" interchangeably throughout our study to reference firm use of transactions that are treated the same (that conform) for book and taxable income and that, further, enable firms to lower their tax liabilities.
} 
noncompliance and do not find a significant association with book-tax conforming transactions. However, as their focus is on the aggressive end of tax avoidance behavior (tax noncompliance measured by tax audit corrections) in one country (China), it is not clear how their findings would generalize to our setting. Thus, it is an open question whether and to what extent book-tax conformity influences tax-induced earnings management more broadly.

We rely on unconsolidated accounting information for a sample of 123,314 firms in 23 European countries over 2005-2013 from Bureau van Dijk's (BvD) Amadeus to investigate this research question. Thus, similar to Beuselinck et al. (2019), we use data structured at the unconsolidated level to investigate earnings management. ${ }^{3} \mathrm{We}$ first perform baseline and validation tests that identify and quantify tax-induced earnings management in an international setting prior to considering the role of book-tax conformity. We find that entities in jurisdictions with higher statutory tax rates report lower pre-tax book income all else equal, indicative of tax-induced earnings management. In terms of economic magnitude, the results suggest that for the average firm in our sample an increase in the statutory tax rate by 10 percentage points relates to reporting a 8.2 percent lower book income. For U.K. (German) firms in our sample, such a tax rate change would equate to $\$ 51.3$ billion ( $\$ 20.3$ billion) lower pre-tax book income. For comparison, the recent U.S. tax reform lowered the federal statutory tax rate by 14 percentage points ( 35 to 21 percent). If U.S. firms respond similarly to the effect we observe in our cross-country analysis, then U.S. firms would report higher book income by about 12.8 percent as a function of reduced conforming tax avoidance incentives.

\footnotetext{
${ }^{3}$ We use the term "entity" throughout to refer to the unconsolidated firm unit in a consolidated firm ownership structure. Our sample includes both parent entities and subsidiary entities within a consolidated firm structure.
} 
We next perform a series of tests to validate whether results with our baseline analysis allow us to make inferences conforming tax avoidance. A potential alternative explanation could be a shifting of profits from high to low tax jurisdictions that does not alter consolidated book income. To consider this, throughout our analysis, we do not limit our sample to MNEs with the ability to shift profits across jurisdictions, but also consider purely domestic firms without this opportunity. Given that we find our result in a subsample of purely domestic firms as well as a subsample of MNE firms, this is our first indication that our results are not consistent with a profit-shifting explanation. Results from additional validation tests further support inferences with book-tax conforming transactions. In particular, results are robust if we re-estimate the analysis attempting to control for where else the profit could have been shifted within the EU or if we limit analysis to firms without subsidiaries in tax havens. Further, consistent with the importance of public market pressure for manipulation of reported consolidated profits, we also find that book income is less responsive to tax rates for public firms relative to private firms without this pressure. Finally, we investigate whether our analysis is able to capture a specific strategy for manipulating consolidated earnings surrounding a tax reform in Germany. Collectively, results from these tests support our use of the baseline specification to investigate taxinduced earnings management and provide evidence that our results are not alternatively explained by within-company profit-shifting.

With the above methodology in place, we move forward to examine the influence of book-tax conformity on tax-induced earnings management. To investigate this question, we re-estimate our baseline analysis after incorporating a proxy for the degree of book-tax conformity based on common measures (e.g., Tang 2015) in the entity's resident country and its interaction with the statutory tax rate. We predict and find results consistent with entities in countries with greater book-tax conformity engaging in additional tax-induced 
earnings management. In particular, entities are more willing to report lower pre-tax book income in response to higher statutory tax rates when book-tax conformity is higher. Corresponding findings hold for both a cross-sectional analysis of the average level of book-tax conformity in jurisdictions as well as for an analysis of changes in book-tax conformity over time. They are also robust to the use of alternative proxies for book-tax conformity developed in prior literature (Atwood, Drake, and Myers 2010). Thus, while prior research shows that greater book-tax conformity curbs certain forms of tax avoidance (nonconforming tax avoidance), our results suggest that greater book-tax conformity can increase conforming tax avoidance behavior.

In addition to the policy debates mentioned above, this study contributes to three streams of accounting literature: 1) book-tax conformity, 2) tax-induced earnings management (conforming tax avoidance), and 3) international profit-shifting. Regarding the costs and benefits of book-tax conformity (Guenther, Maydew, and Nutter 1997; Hanlon and Shevlin 2005; Hanlon, Maydew, and Shevlin 2008; Hanlon and Maydew 2009; Atwood, Drake, and Myers 2010), our results extend this discussion in three ways. First, while the above literature suggests that greater book-tax conformity can affect different attributes of book earnings directly, such as the information content of reported earnings, our results suggest that a second channel through which conformity can influence reported earnings is by amplifying the effect of an alternative policy (statutory tax rates) on reported earnings. ${ }^{4}$ Second, while prior literature provides evidence supporting predictions that greater conformity mitigates one type of tax avoidance (nonconforming tax avoidance)

\footnotetext{
${ }^{4}$ Guenther, Maydew, and Nutter (1997) use the switch from the cash method to the accrual method for certain firms with the U.S. Tax Reform Act of 1986 to assess the implications of greater book-tax conformity for the shifting of income from a high-tax period to a low-tax period. However, because the required switch in the accounting method coincided with the only change in the statutory tax rate during their sample period, the results do not allow an inference about how greater conformity altered the sensitivity of reported book income to the level of statutory tax rates, the question we examine in our analysis.
} 
(Atwood et al. 2012; Tang 2015), our results suggest that an alternative type of tax avoidance (conforming tax avoidance) may actually increase with greater conformity. Finally, our finding that book-tax conformity amplifies tax-induced earnings management is important given that prior literature finds mixed evidence when examining the effect of conformity for earnings management in general (i.e., not induced by taxes). Watrin, Ebert, and Thomson (2014) and Blaylock, Gaertner, and Shevlin (2017) find a positive association of book-tax conformity and earnings management, while Atwood et al. (2012) and Tang (2015) find the opposite result and Leuz, Nanda, and Wysocki (2003) do not find a significant association. One implication of our findings for this literature may be that conformity has a heterogeneous effect on different types of earnings management incentives. Thus, this may be one reason why prior literature finds mixed results when examining the effect on more general earnings management proxies like discretionary accruals.

The second stream of research we contribute to discusses tax-induced earnings management (conforming tax avoidance) and the trade-offs of financial and tax reporting. In particular, prior literature documents conforming strategies that shift transactions across periods surrounding particular tax law changes (Scholes, Wilson, and Wolfson 1992; Guenther 1994; Maydew 1997; Roubi and Richardson 1998; Dobbins et al. 2018). A related stream of research alternatively examines the role of financial and tax reporting incentive trade-offs with specific transactions: public or private operation decisions (Penno and Simon 1986), option dispositions (Matsunaga, Shevlin, and Shores 1992), aggressive tax positions (Cloyd, Pratt, and Stock 1996), divestitures (Klassen 1997), and option grants (Klassen and Mawani 2000). Our study adds to this literature by adapting and validating a methodology for examining tax-motivated earnings management more generally through 
manipulation of book earnings across countries and over time. We then use this method to document and quantify conforming tax avoidance in an international setting.

Our methodology for studying conforming tax avoidance complements an alternative methodology proposed by Badertscher et al. (2019) in the following ways. First, while their methodology focuses on the tax burden implications of conforming tax avoidance (i.e., the product of tax rate and tax base), our study focuses on the effect that statutory tax rates have on the tax base, which in the case of conforming tax avoidance equals book earnings. ${ }^{5}$ It is important for policy evaluations to identify and quantify the response of book income to tax rate changes, as such behavior affects not only tax revenues and tax burdens of firms, but is also relevant for financial reporting outcomes and the information available in earnings. Second, researchers cannot apply the approach in Badertscher et al. (2019) to settings that rely on unconsolidated earnings data as unconsolidated international data sets do not provide the tax variables used in their study that capture tax deferral and other forms of conforming tax avoidance. ${ }^{6}$ Use of unconsolidated international data for tax analysis is important, particularly for multinationals, because tax policies (such as tax rates) in countries outside the U.S. are predominantly applied on a territorial (jurisdiction-specific) basis whereas in the U.S. federal tax policies have typically been applied on a worldwide (consolidated) basis. Moreover, our approach focusing on the tax base effect is not subject to recent critiques raised with residual-based dependent variables (Chen, Hribar, and Melessa 2018).

\footnotetext{
5 This approach with examining the base effect to infer tax avoidance behavior is in line with the public economics literature that examines the sensitivity or responsiveness of taxable income to statutory tax rates to make inferences about tax avoidance behavior (e.g., Feldstein 1995, 1999; Saez 2010). This approach has also been used in the profit shifting literature that examines income responsiveness to tax rate differentials (e.g., Huizinga and Laeven 2008).

${ }^{6}$ Instead, unconsolidated data in Amadeus provides a total taxes variable (current plus deferred taxes), which does not capture intertemporal deferral strategies. As such strategies are an important source of conforming tax avoidance, tax variables in Amadeus are not appropriate to proxy for tax-induced earnings management.
} 
We also contribute to the literature on profit-shifting (e.g., De Simone 2016; De Simone, Klassen, and Seidman 2017). Results with our baseline analysis and related validation tests suggest that analysis commonly used in the public economics and accounting literatures to examine profit-shifting can also be used to investigate an alternative tax avoidance strategy. In particular, results in our baseline tests suggest the designs in these studies can be used as well to evaluate tax-induced earnings management (i.e., conforming tax avoidance).

\section{PRIOR LITERATURE AND HYPOTHESIS DEVELOPMENT}

\section{Background on methods for examining tax induced earnings management}

Tax avoidance is often defined broadly as any reduction to a firm's explicit taxes (Dyreng, Hanlon, and Maydew 2008; Hanlon and Heitzman 2010). Most measures of tax avoidance used in prior literature are constructed from public disclosures in firm financial statements as opposed to tax returns. However, most of these measures do not allow for analysis about conforming tax avoidance (see also Hanlon and Heitzman 2010). Two common measures of tax avoidance are GAAP effective tax rates (GAAP ETRs) and cash effective tax rates (Cash ETRs). Both use a ratio of one measure of firm tax liabilities (the numerator) divided by a measure of a firm's (adjusted) pre-tax book income (the denominator). Neither ETR measure allows for inferences about conforming tax avoidance because a lowering of taxes through strategies that similarly reduce both taxable income and pre-tax book income cannot be captured in the ETR measures. A third common approach relates to using book-tax differences. As conforming tax avoidance affects both book income and taxable income, by definition it does not result in a book-tax difference. Hence, it would not produce variation in a book-tax difference-based measure.

Hanlon and Heitzman (2010) discuss two measures that could potentially capture conforming tax avoidance, cash taxes paid divided by cash flow from operations (discussed 
in their footnote 49) and unrecognized tax benefits. However, as they explain, both measures would only capture a subset of conforming tax avoidance strategies and neither measure has been applied yet in empirical research. Therefore, the above common tax avoidance measures have not allowed for broad inferences about conforming tax avoidance either in a U.S. setting or an international context.

\section{Prior literature on tax-induced earnings management}

Most of the prior literature that examines tax-induced earnings management (conforming tax avoidance) uses tax law changes surrounding the U.S. Tax Reform Act of 1986 (henceforth, "the TRA") to shift various pre-tax book income accounts across time periods in response to tax incentives. Specifically, Scholes, Wilson, and Wolfson (1992) examine the shifting of gross profits and selling, general, and administrative expenses surrounding the TRA. Alternatively, Guenther (1994) examines shifting of accruals, and Maydew (1997) analyzes shifting of non-recurring versus recurring revenues and expenses for firms with net operating losses. Roubi and Richardson (1998), and Dobbins et al. (2018) provide evidence for such intertemporal income shifting related to changes in statutory and marginal tax rates in other countries (Canada, Germany, Malaysia, and Singapore).

An important source of tension discussed in these studies is the financial reporting cost with reporting lower performance (book income) and the non-tax operational costs of intertemporal income shifting, which could deter firms from responding to these tax incentives. Examples of financial reporting costs include debt covenant violations or compensation contract concerns that are often influenced by reported book income. Further, operational costs could entail customer concerns because these types of tax avoidance strategies can require delays with sales or deliveries. Despite these costs, this literature provides evidence of conforming tax avoidance via the tax-induced intertemporal shifting of income. Penno and Simon (1986) and Cloyd, Pratt, and Stock (1996) further 
provide evidence that - as a consequence of higher financial reporting costs - publicly listed firms are less active in tax-induced earnings management than private firms.

Two recent studies focus on conforming tax avoidance strategies more broadly. Badertscher et al. (2019) develop a measure of conforming tax avoidance for U.S. firms at a firm consolidated entity level. The measure is the residual or unexplained variation in total worldwide explicit tax avoidance (as proxied by the ratio of cash taxes paid to lagged total assets) when regressed on proxies for nonconforming tax avoidance (e.g., a book-tax difference-based measure) and other firm attributes. They use this measure to show that public firms and firms with high capital market pressure are less active in conforming tax avoidance than private firms and other firms with low capital market pressure. ${ }^{7}$ Hundsdoerfer and Jacob (2019) use external shocks in sales to investigate conforming tax avoidance through one particular channel, manipulation of operating costs. In particular, they investigate the asymmetric response of tax avoidance through this channel to contribute to the management accounting literature on cost stickiness.

\section{Prior literature on consequences of book-tax conformity}

Advocates of greater conformity predict that greater book-tax conformity mitigates negative aspects of manipulation or planning with book and taxable incomes. In particular, they predict that this would curtail firms' ability to both simultaneously overstate book earnings and understate taxable income with corporate tax shelters (Desai 2005; Joint Committee on Taxation 2006). Consistent with this, Atwood et al. (2012) provide evidence for less nonconforming tax avoidance in jurisdictions with high book-tax conformity. Tang

\footnotetext{
7 A related stream of research examines the role of financial and tax reporting incentive trade-offs with different transactions, e.g., public or private operation decisions (Penno and Simon 1986) or option dispositions (Matsunaga, Shevlin, and Shores 1992). Mills and Newberry (2001), find that public firms engage in a greater degree of nonconforming tax avoidance than private firms. These studies do not attempt to develop a broad measure or methodology for evaluating and quantifying conforming tax avoidance.
} 
(2015) confirms this finding and further provides evidence that book-tax conformity is negatively associated with earnings management based on discretionary accruals.

Opponents of book-tax conformity argue that the differences between book and tax reporting result because of differences in the purposes (desired benefits) of providing these reported values. Constraining these values to be more similar mitigates the ability of each value to provide these unique benefits. Specifically, prior research suggests that greater conformity reduces the information content and overall quality of book earnings. Results show that greater book-tax conformity reduces the association of annual book earnings with concurrent stock returns (Hanlon, Maydew, and Shevlin 2008) and their associations with future earnings and cash flows (Atwood, Drake, and Myers 2010). Further, greater booktax conformity reduces the incremental ability of book and estimated taxable income to explain stock returns (Hanlon, Laplante, and Shevlin 2005). Watrin, Ebert, and Thomsen (2014) and Blaylock, Gaertner, and Shevlin (2015) also provide evidence suggesting greater earnings management activity for firms in systems with high book-tax conformity.

\section{Hypothesis development}

While prior literature has examined the direct implications of book-tax conformity for attributes of reported book income, our study builds on this literature by considering whether book-tax conformity alters the responsiveness of reported book income to an alternative policy, namely tax rate policy. Prior literature suggests alternative predictions for how greater conformity could influence tax-induced earnings management. Two studies suggest that higher conformity may curb taxes saved through nonconforming tax avoidance strategies (Atwood et al. 2012; Tang 2015). Therefore, firms may be more willing to engage in additional conforming tax avoidance to preserve tax savings with greater conformity. Further, greater conformity, by definition, should increase the set of opportunities for 
conforming tax avoidance. Following these arguments that book-tax conformity provides more opportunity and incentives for conforming tax avoidance, we hypothesize:

H1: A higher degree of book-tax conformity is positively associated tax-induced earnings management (conforming tax avoidance).

However, there are also arguments for a potential negative association of conformity and tax-induced earnings management. The findings of Hanlon et al. (2005) and Hanlon et al. (2008) suggest that the market may have less high-quality information with greater conformity. Consequently, the available information in book earnings may carry more weight with shareholders as conformity increases. From this perspective, firms may even be less willing to manipulate their book signal downward in response to higher conformity. Chan, Lin, and Mo (2010) find no significant evidence that a reduction in conformity from IFRS adoption altered noncompliance through book-tax conforming transactions for Chinese firms. However, as IFRS adoption is a specific change of booktax conformity and tax noncompliance is at the aggressive end of tax avoidance, it remains open how these findings relate to the association of book-tax conformity and conforming tax avoidance in general.

\section{RESEARCH DESIGN AND SAMPLE}

\section{Baseline specification}

Our approach assumes that the normal ("true") economic profit of an entity absent tax incentives is a function of available capital assets, labor, and productivity in line with the literature on international income shifting by Grubert and Mutti (1991), Hines and Rice (1994), and Huizinga and Laeven (2008). This approach uses a natural log transformation of the Cobb-Douglas production function to explain normal profits. We then include the corporate statutory tax rate in the entity's resident jurisdiction to capture the tax incentive to manage pre-tax book earnings downward as this is the rate that the entity would apply 
to the unmanaged tax base (book pre-tax profit) absent manipulation of earnings. This results in the following model:

$\log$ PTI $_{i, t}=\beta_{0}+\beta_{1}$ Tax Rate $_{j, t}+\beta_{2}$ Log $_{\text {Assets }}, t+\beta_{3} \log$ Compensation $_{i, t}$

$$
+\beta_{4} \log G D P_{j, t}+\beta_{5} \log \text { GDP per Capita } \text { jat, }+\alpha_{i}+\gamma_{t}+\varepsilon_{i, t}
$$

where the dependent variable is the natural logarithm of pre-tax book income $\left(\log P T I_{i, t}\right)$ for entity $i$ in country $j$, in year $t$. Tax Rate $e_{j, t}$ is the top marginal statutory corporate income tax rate in entity $i$ 's resident jurisdiction $j$ in year $t$. If entities manipulate their book earnings (tax base) intertemporally in response to statutory tax rates in line with prior literature on tax-induced earnings management (e.g., Guenther 1994; Maydew 1997), we expect a negative coefficient of $\operatorname{Tax}_{\text {Rate }_{j, t}}\left(\beta_{1}\right)$. The natural logarithms of total assets (Log Assets L $\left._{i, t}\right)$ and employee compensation expense (Log Compensation ${ }_{i, t}$ ) proxy for the capital assets and labor. We include additional controls from prior literature. The logarithms of GDP and GDP per capita $\left(\log G D P_{j, t}\right.$ and $\log G D P$ per apita $\left._{j, t}\right)$ proxy for the size of the economy and productivity in a country. Finally, to account for time-invariant features of the entity (and thus also the firm), we include firm fixed effects for each entity $\left(\alpha_{i}\right)$. We also include year fixed effects $\left(\gamma_{t}\right)$ to account for variation in macroeconomic conditions over time. In an alternative specification, we replace firm fixed effects with country fixed effects and industry fixed effects at the two-digit level and add dummy variables as in De Simone (2016) to account for differences in accounting rules and financial reporting incentives for parents $\left(\right.$ Parent $\left._{i}\right)$ as well as for listed firms $\left(\right.$ Public $\left._{i}\right)$. We cluster standard errors at the country-industry level, with industry based on one-digit SIC codes.

Before describing how we adapt this baseline specification above to test $\mathrm{H} 1$, we first outline a series of validation tests to rule out an alternative explanation. In particular, our interest is in making inferences about firm manipulation of consolidated earnings in response to tax incentives indicative of conforming tax avoidance. In contrast, an 
alternative explanation for a negative coefficient on Tax $_{\text {Rate }}$ j,t could be profit shifting across jurisdictions within the firm that does not have an effect on consolidated profits. ${ }^{8}$

\section{Validation tests with the baseline specification}

Unlike prior literature on intracompany profit shifting of multinationals, we do not limit our analysis throughout to MNEs but instead also include domestic firms. As purely domestic firms have no opportunity for cross-jurisdiction income shifting, a negative coefficient on Tax Rate ${ }_{j, t}$ in equation (1) $\left(\beta_{1}\right)$ represents conforming tax avoidance for this subsample of firms as opposed to profit-shifting and suggests that this interpretation also holds for our broader sample that contains MNEs. ${ }^{9}$

Further, we perform three additional validation tests with equation (1) to assess whether our results are more likely to be explained by tax-induced manipulation of consolidated earnings as opposed to intracompany profit shifting. In a first set of tests, we attempt to control for the ability of multinational firms to shift income among jurisdictions. We re-estimate the analysis for unconsolidated entities but add the control variable $\log$ Group Profit $t_{i, t}$ for EU entities of multinational firms where the income could have been shifted. We define Log Group Profit $t_{i, t}$ as the logarithm of the aggregate sum of all profits of the group less entity $i$ 's profit. Thus, Log Group Profit $t_{, t}$ proxies for any income than might have been shifted away within the group. Of course, we are only able to control for the book income of the group members for which we have data access. While Amadeus provides the ownership information for European groups on a worldwide basis, financial

\footnotetext{
${ }^{8}$ While more recent accounting literature predominantly uses a similar approach for interpretations about international profit shifting, the public economics literature often uses this approach of examining the sensitivity or responsiveness of income to tax rates to examine many alternative tax avoidance strategies (e.g., Feldstein 1995, 1999; Saez 2010). Thus, collectively, prior literature does not suggest that inferences with this design are limited to interpretations about cross-jurisdictional profit shifting. Nevertheless, as international profit shifting is a viable, alternative tax avoidance strategy that could explain the predicted effect with equation (1), we give this alternative interpretation significant consideration in our validation tests. ${ }^{9}$ To the extent that implicit taxes or tax incidence might influence our results whereby firms are able to pass on part of their tax burden to other stakeholders, this would predict a positive coefficient on Tax Rate. A negative Tax Rate coefficient represents a lower bound estimate of tax-induced earnings management.
} 
statement information is only available for European entities. Thus, controlling for $\log$ Group Profit $t_{i, t}$ may not capture international income shifting to entities in non-European tax havens. However, we are able to identify firms with subsidiaries in tax havens on a worldwide basis. To account for the role of shifting to tax havens with equation (1), we alternatively re-estimate the equation for a subsample of multinationals without subsidiaries in tax havens. ${ }^{10}$ If the negative association between Tax Rate ${ }_{j, t}$ and $\log P T I_{i, t}$ conversely represents a shifting of income to tax havens as opposed to tax-induced manipulation of consolidated earnings, then we should be less likely to observe the negative association in the subsample that does not have haven subsidiaries.

As a second set of validation tests, we refer to Badertscher et al. (2019). To help validate their residual-based conforming tax avoidance measure for U.S. firms, Badertscher et al. (2019) show that public firms have lower values of their conforming tax avoidance measure than private firms. They interpret these results as support that the residual-based measure represents conforming tax avoidance as public firms are expected to face higher financial reporting costs with (tax-induced) earnings management and, therefore, would be less willing to engage in such behavior. Building on this prediction and their results, we expect that if our baseline model captures conforming tax avoidance with the negative association between pre-tax book income and statutory tax rates, this negative association will be muted for public firms relative to private firms. We revise equation (1) as follows:

$$
\begin{aligned}
\log _{\text {PTI }_{i, t}=} & \theta_{0}+\theta_{1} \text { Tax Rate }_{j, t} \times \text { Public }_{i}+\theta_{2} \text { Tax }_{\text {Rate }}, t+\theta_{3} \text { Log Assets }_{i, t} \\
& +\theta_{4} \text { Log Compensation }_{i, t}+\theta_{5} \text { Log GDP }_{j, t}+\theta_{6} \text { Log GDP per Capita }_{j, t} \\
& +\theta_{7} \text { Parent }_{i}+\theta_{8} \text { Public }_{i}+c_{j}+n_{k}+\gamma_{t}+\varepsilon_{i, t} .
\end{aligned}
$$

We predict that the coefficient of the interaction term, $\operatorname{Tax}_{\text {Rate }_{j, t}} \times \operatorname{Public}_{i}\left(\theta_{1}\right)$, is positive, which represents a mitigation of the negative coefficient we expect on Tax Rate $_{j, t}$

\footnotetext{
${ }^{10}$ Note that a unique definition or list of tax havens does not exist. The determination of tax haven affiliates in this study relies on the list of tax havens in OECD (2009). For more detail see Appendix 2.
} 
$\left(\theta_{2}\right)$. As the dummy variable Public $i$ does not vary over time, we use a cross-sectional specification including country fixed effects $\left(c_{j}\right)$ and industry fixed effects (based on twodigit SIC codes) $\left(n_{k}\right)$ instead of firm fixed effects. Observing a mitigation effect with public firms is more consistent with a tax-induced earnings management interpretation than an international income-shifting interpretation of our findings, as cross-jurisdictional income shifting does not incur additional financial reporting costs for public firms.

As a third and final set of validation tests, we analyze the impact of a large tax cut in Germany in 2008 on a specific channel for tax-induced earnings management. We focus on a single treated country in this analysis to attempt to keep country characteristics (e.g., tax system characteristics) as homogenous as possible. The specific channel of tax-induced earnings management we examine is how entities alter the timing of provisions, ${ }^{11}$ i.e. accruals that provide firms with discretion about the timing of when to recognize business expenses for both book and tax purposes. While there is discretion in timing with provisions, German local GAAP require that provisions in tax accounts are in general congruent with provisions in financial reporting. Thus, a provision can be used for tax deferral strategies as one channel of conforming tax avoidance as discussed in Scholes, Wilson, and Wolfson (1992), Guenther (1994), and Maydew (1997). At the same time, provisions, which shift income across time, are not expected to capture cross-sectional, intrafirm income shifting. Therefore, evidence of management of provisions surrounding the German Business Tax Reform of 2008 (BTR 2008) would be consistent with conforming tax avoidance but would not support a within-company income shifting interpretation of equation (1). We perform a difference-in-differences analysis related to this tax law change with an adjusted version of equation (1):

\footnotetext{
${ }^{11}$ Corresponding to $\S 249$ German local GAAP, provisions can be recognized for "uncertain liabilities", i.e. future expected payments like tax payments, deferred compensation for employees, payments for damages and the violation of rights, or even stripping costs.
} 
Log Prov $_{i, t}=\delta_{0}+\delta_{1}$ Treat $_{j} \times$ TPeriod $_{t}+\delta_{2}$ Log $_{\text {Assets }}, t+\delta_{3}$ Log Compensation $_{i, t}$

$$
+\delta_{4} \log G D P_{j, t}+\delta_{5} \log G D P \text { per } \text { Capita }_{j, t}+\alpha_{i}+\gamma_{t}+\varepsilon_{i, t}
$$

where we replace the log of pre-tax income $\left(\log P T I_{i, t}\right)$ with the log of provisions $\left(\log \operatorname{Prov}_{i, t}\right)$. We then limit our sample analysis to German entities as our treatment group (Treat $t_{j}$ equal to one) and a set of control entities in countries that are closely related to and have a common border with Germany but that had no relevant changes in the corporate income tax rate during the observation period (Treat ${ }_{j}$ equal to zero). This control group includes all entity observations in Austria, Belgium, France and Poland. ${ }^{12}$ Our indicator for the post treatment period $\left(\right.$ TPeriod $\left._{t}\right)$ is equal to one in 2008 and equal to zero for earlier years. All other variables are defined as in equation (1). The inclusion of firm and year fixed effects in equation (3) absorbs the main effects of Treat ${ }_{j}$ and TPeriod $_{t}$. As the number of countries in this analysis is limited and the main effect of the BTR 2008 is only relevant for one country, we abstain from clustering standard errors by country-industry clusters, but instead cluster standard errors at the level of the firm group (GUO).

The BTR 2008 reduced the statutory tax rate on corporate income (including local taxes) by about 10 percentage points and, thus, reduced the incentive to engage in conforming tax avoidance by reporting higher provisions to reduce book income. Therefore, we expect the coefficient on the interaction term, $\operatorname{Treat}_{j} \times \operatorname{TPeriod}_{t}\left(\delta_{1}\right)$ to be negative suggesting that German firms were more willing to report higher book income (lower provision expenses) after the tax rate was reduced in January 2008.

\footnotetext{
${ }^{12}$ France had a very small corporate income tax rate reduction from $33.83 \%$ to $33.33 \%$ in 2006 . However, as we show in Figure 1, this did not have a significant effect on the provisions of the control group in the preBTR 2008 period and, thus, does not raise concern for the parallel trends assumption with the control group.
} 


\section{Research design to analyze the association between book-tax conformity and tax- induced earnings management}

To test H1 related to the influence of book-tax conformity on tax-induced earnings management, we perform two alternative empirical tests. As a first cross-sectional test, we compare tax-induced earnings management in countries with an above-average book-tax conformity level in our observation period relative to this type of earnings management in countries with a below-average book-tax conformity level. We set a dummy variable, BTaxC High, equal to one for entities in a country with an above average book-tax conformity over the whole observation period and set it equal to zero otherwise. ${ }^{13} \mathrm{We}$ interact BTaxC High $h_{j}$ with Tax Ratej,t and expect a negative regression coefficient for both Tax Rate $j, t$ and its interaction term Tax Rate Th,t $\times$ BTaxC High $_{j}$, suggesting that entities engage in additional tax-induced earnings management in countries with higher book-tax conformity. As average values of book-tax conformity do not vary over time for a given country, we initially include industry fixed effects in place of firm fixed effects, arriving at the following equation:

$$
\begin{aligned}
& \log P_{T I} I_{i, t}=\lambda_{0}+\lambda_{1} \text { Tax Rate }_{j, t} \times \text { BTaxC High }_{j}+\lambda_{2} \text { Tax Rate }_{j, t}+\lambda_{3} \text { BTaxC High }_{j} \\
& +\lambda_{4} \log \text { Assets }_{i, t}+\lambda_{5} \log \text { Compensation }_{i, t}+\lambda_{6} \log G D P_{j, t} \\
& +\lambda_{7} \log \text { GDP per Capita }, t+n_{k}+\gamma_{t}+\varepsilon_{i, t .}
\end{aligned}
$$

For the calculation of BTaxC High, we use the book-tax conformity measures in Watrin, Ebert, and Thomsen (2014), who developed a measure specifically for Amadeus data and Tang (2015) (for the calculation of these measures see Appendix 3). In an untabulated robustness test, we also estimate the equation with the book-tax conformity measure in Atwood, Drake and Myers (2010), where results support our findings with our two primary measures above. We do not use this as a primary measure because the

\footnotetext{
${ }^{13}$ Results are robust if we alternatively define $B \operatorname{Tax} C H i g h_{j}$ as above the median.
} 
methodology requires the use of Compustat Global Legacy data, which ends in 2007. Given that our sample period is 2005-2013, this only allows for three years of overlap for the analysis and a significant reduction in our sample by about 70 percent of observations. The above measures capture the overall degree of book-tax conformity in contrast to the designs in Hanlon, Laplante, and Shevlin (2005) and Hanlon, Maydew, and Shevlin (2008) that focus on one source of book-tax conformity.

As a second test and to address concerns about using a static book-tax conformity measure, we next focus on significant changes in book-tax conformity for a country over time. We define a change as significant if a country with an above-average value of booktax conformity in year $t-1$ changes to a below-average value in year $t$ and vice versa. In the case of a significant increase (decrease) in book-tax conformity for a country, BTaxC Change $_{j, t}$ takes a value of one (minus one) and is set equal to zero otherwise. We interact BTaxC Change $e_{j, t}$ with Tax Rate $e_{j, t}$ and again predict a negative coefficient for this interaction term, indicating that an increase in book-tax conformity is associated with additional taxinduced earnings management. This approach allows us to consider firm fixed effects as we specifically consider the variation in book-tax conformity over time. Thus, we estimate the following equation:

$$
\begin{aligned}
& \log P_{T I} I_{i, t}=\gamma_{0}+\gamma_{1} \text { Tax }_{\text {Rate }}{ }_{j, t} \times \text { BTaxC Change }_{j, t}+\gamma_{2} \text { Tax Rate }_{j, t}+\gamma_{3} \text { BTaxC Change }_{j, t} \\
& +\gamma_{4} \log \text { Assets }_{i, t}+\gamma_{5} \log \text { Compensation }{ }_{i, t}+\gamma_{6} \log G D P_{j, t} \\
& +\gamma_{7} \log \text { GDP per Capitaj,t }+\alpha_{i}+\gamma_{t}+\varepsilon_{i, t} \text {, }
\end{aligned}
$$

where variables are defined previously. In untabulated analysis, results are generally robust if we re-estimate equation (5) alternatively using country fixed effects and industry fixed effects instead of firm fixed effects as well as incorporate dummy variables for whether entities are public firms and parents rather than subsidiaries. 


\section{Sample selection and descriptive statistics}

We use unconsolidated financial statement and ownership data for European companies from 2005 to 2013 from Bureau van Dijk's Amadeus database. Amadeus contains detailed financial statement and ownership information for European firms. The ownership information is based on the last year in the sample (2013) and provides information on worldwide shareholdings of European parents. We begin by restricting the sample to EU-domiciled parents ("global ultimate owners" or GUOs) and their EU-28 domiciled subsidiaries with available company name, accounting, and active status data. ${ }^{14}$ We then remove firms that are inactive, in regulated industries (financial and insurance institutions), where parent versus subsidiary classification is unclear, and where status as a multinational versus domestic firm is unclear. ${ }^{15}$ We require complete data for accounting variables based on local GAAP data ${ }^{16}$ and on a majority of shareholders. We further exclude observations with implausible values (e.g., with negative assets), losses, or total assets of less than $\$ 500,000$ (micro firms). These sample adjustments ensure that our sample firms have sufficient incentives and economic resources for conforming tax avoidance.

Finally, as we cluster standard errors at the country-industry level (industry based on one-digit SIC codes), we require that we have at least 30 observations for each countryindustry combination. This results in a sample of 426,593 entity observations in $23 \mathrm{EU}$ member states, where 142,667 observations relate to parent entities (GUOs) and 283,926

\footnotetext{
${ }^{14}$ We have selected firms of all countries that were member of the European Union at the end of our sample period. Croatia became the $28^{\text {th }}$ member of the European Union on July 1, 2013. Due to data restriction requirements (see Table 1, Panel A), the final sample comprises observations from all EU-28 countries except Cyprus, Greece, Latvia, Lithuania, and Malta.

${ }^{15}$ We define a parent and its subsidiaries as domestic if the parent does not hold any stake in any firm that is settled abroad (even with very small international shareholdings). In line with the literature on international income shifting (e.g., Huizinga and Laeven 2008), we classify firms as MNEs if either the parent or at least one of its majority-owned subsidiaries is located in another country than other group members. We exclude all observations of minority shareholdings, i.e. where the parent does not hold more than 50 percent.

${ }^{16}$ The number of observations with unconsolidated IFRS reporting is relatively low in the dataset and the distribution does not correspond to the distribution of economic activity in Europe. Further, to take advantage in cross-country variation in book rules as they contribute to book-tax conformity, we exclusively utilize data with local GAAP that has more variation in book reporting across European countries.
} 
to subsidiary entities. We provide a detailed breakdown of our sample construction process in Table 1, Panel A. Table 1, Panel B breaks down observations by country and whether observations relate to firms classified as multinationals (MNEs) versus domestic entities. A relatively high number of observations is located in Belgium, France, Germany, Italy, Sweden, and the United Kingdom. Apart from Belgium, this should be driven by the economic role of these countries. In contrast, we observe smaller subsets of observations in Austria, Hungary, Ireland, Luxembourg, and Slovenia. Overall, the country break down broadly corresponds to the distribution of economic activity in Europe.

We report the statutory corporate income tax rates that include the top federal rates as well as average local taxes and surtaxes by country and year in Table 2. Tax rates are taken from KPMG (2006) and KPMG's corporate tax rate tables. ${ }^{17}$ Consistent with the idea that tax rates are generally decreasing over time, more than half of the European countries in our sample (16) have at least one tax rate decrease whereas only a few of these countries (4) have at least one tax rate increase. Corporate statutory tax rates in our sample vary between 10.0 percent (Bulgaria) and 38.4 percent (Germany).

Finally, we report descriptive statistics for the full sample, domestic subsample, and MNE subsample in Table 3, Panels A, B, and C, respectively. The average pre-tax book income, total assets, and total employee compensation in the full sample (Panel A) are \$3.7 million, $\$ 40.9$ million, and $\$ 6.5$ million, respectively. The sample is split relatively evenly by domestic (49.7 percent) versus MNE (50.3 percent) observations. Pre-tax book income and size differ between the domestic and MNE subsamples (Panels B and C, respectively), where domestic firms have lower book income, assets, and total employee compensation

17 https://home.kpmg/xx/en/home/services/tax/tax-tools-and-resources/tax-rates-online/corporate-tax-ratestable.html. 
relative to MNE firms. However, the tax rates and country-level characteristics do not substantially differ between domestic and MNE subsamples.

\section{RESULTS}

\section{Baseline analysis for tax-induced earnings management}

We report estimates for equation (1) in Table 4. In particular, columns (1) and (4), (2) and (5), and (3) and (6) use the full sample, domestic sample, and MNE sample, respectively. The first three columns include firm and year fixed effects consistent with equation (1), whereas the last three columns include country, industry, and year fixed effects for robustness. Consistent with firms reporting lower pre-tax book income in response to higher tax rates, which we interpret as tax-induced earnings management, we observe a negative coefficient estimate on Tax Rate $_{j, t}$ in all six columns with statistical significance at the 10 percent level or better. For the full sample, our specification with firm fixed effects (country fixed effects) suggests a semi-elasticity of -0.860 (-0.793). Thus, an increase in the statutory tax rate of 10 percentage points implies a reduction in reported book income induced by conforming tax avoidance by 8.2 (7.6) percent. ${ }^{18}$ Results for the domestic and MNE subsamples lie in a similar range (elasticity estimates between -0.972 and -0.745 , respectively) if we include firm fixed effects and year fixed effects (our main specification). In our alternative regression approach with industry, country, and year fixed effects, the range of estimates is wider (elasticity estimates between -0.521 and -1.257 ), consistent with lower precision of estimates with this specification.

\footnotetext{
${ }^{18}$ Due to our logarithmic dependent variable, magnitude interpretations for the full sample are calculated by exponentiating the coefficient estimate. To account for a 10 percentage point tax rate change, this calculation for col. (1) is $100 x(\exp (-0.860(0.10 / 1))-1)=-8.24 \%$ and for col. (4) is $100 x(\exp (-0.793(0.10 / 1))-1)=-7.62 \%$.
} 


\section{Validation tests for tax induced earnings management}

\section{Validation tests to assess international income-shifting}

We next assess whether income shifting across countries contributes to the results we observe in Table 4. First, it is important to point out that our outcome variable in equation (1) is pre-tax book income. Thus, to the extent that international income shifting strategies alter taxable income but not book income, this would not be captured in the Tax Rate $_{j, t}$ coefficient estimate. Additionally, as an initial indication that results are unlikely to reflect income shifting across countries, analysis in Table 4 that is run on entities in groups with only domestic operations (columns (2) and (5)) consistently documents a negative, statistically significant coefficient estimate in line with the full sample estimates.

In columns (1)-(4) of Table 5, we report results from two additional tests related to within-company income shifting as an alternative explanation. In columns (1) and (2), we re-estimate the analysis with the full sample and MNE subsample while controlling for the income of the consolidated group itself (Log Group Profit $t_{i, t}$ ) for those MNE entities with available income information excluding the income of entity $i$. In essence, we attempt to hold constant profits in other jurisdictions such that any decrease in entity $i$ 's income cannot be attributed to behavior that would simultaneously increase the income of other group entities. ${ }^{19}$ However, a weakness of the Amadeus data is that it does not offer data coverage for the incomes of entities in non-EU countries, which could relate to non-EU tax havens. For this reason, in columns (3) and (4), we present results for the full sample and the MNE subsample with equation (1) instead excluding MNEs with any subsidiaries in EU or nonEU tax havens. In both specifications, we continue to find a similar negative and

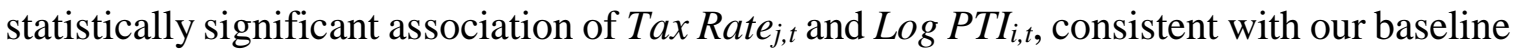

\footnotetext{
${ }^{19}$ In untabulated robustness tests, we alternatively run the analysis with Log Group Profit $t_{i, t}$ instead controlling for the log of group ultimate owner (parent) profits alone as opposed to the aggregated profits of the group (excluding entity $i$ ) and find that results are robust to this alternative definition of the control variable.
} 
results in Table 4. Overall, the results in columns (1)-(4) in Table 5 provide additional evidence that the results with the baseline specification are more likely driven by taxinduced management of earnings as opposed to intracompany income shifting. ${ }^{20}$

\section{Validation tests comparing public and private firms}

In columns (5)-(6) of Table 5, we report the results for estimates of equation (2) that assesses whether public firms, which face higher financial reporting costs tied to their book numbers (Penno and Simon 1986; Cloyd, Pratt, and Stock 1996; Badertscher et al. 2019), are less active in tax-induced earnings management. The columns differ based on the sample used to estimate equation (2), where columns (5) and (6) use the full and the MNE samples, respectively. ${ }^{21}$ Consistent with conforming tax avoidance behavior that is sensitive to financial reporting costs, we observe a positive coefficient estimate (mitigation effect) on the interaction term, Tax Rate $e_{j, t} \times$ Public $_{i}$, where these estimates are statistically significant at the 5 percent level or better.

\section{Validation test on the impact of the German BTR 2008 on provisions}

As a third validation test, we analyze the impact of the German BTR 2008 on provisions using equation (3). We rely on entities in Austria, Belgium, France, and Poland (bordering countries) as control group and identify the effect of the tax rate change by the difference-in-differences interaction term, Treat $_{j} \times$ TPeriod $_{t}$. Before we turn to our regression results, we provide graphical evidence in Figure 1. We document average provisions per year for both the treatment (German entity) and control groups. We demean

\footnotetext{
${ }^{20}$ In untabulated analysis, we conduct two additional tests to account for international income shifting. As a first test, we include the logarithm of debt as an additional control variable, as intra-group debt is a very common channel for cross-jurisdictional income shifting. Second, we account for the analysis in Markle (2016) and test if our results are driven by changes from world-wide taxation to territorial tax regimes as this can alter intrafirm profit shifting opportunities. This second analysis excludes all countries with changes between these regimes (i.e., limiting analysis to countries that maintain territorial tax systems). Results in both of these tests further support our interpretation of the baseline specification.

${ }^{21}$ We do not report estimates with the public vs. private firm analysis for the domestic subsample as there is very little variation in this classification for this subsample. In particular, all but a very small number of domestic firms (851) are private. Nevertheless, despite the low level of variation, we continue to obtain negative and (weakly) significant coefficient estimates on the interaction term with this subsample.
} 
provisions by their average value in the pre-treatment period before 2008 to focus on the relative changes over time. We observe evidence consistent with a parallel trend of provisions between the treatment group and the control group before 2008 suggesting that the parallel trends assumption holds. We also find a structural break after 2008 leading to a significant decrease in German provisions compared to the control group suggesting that the German BTR 2008 reduced tax-induced earnings management through the provisions channel. $^{22}$

We report the regression analysis with equation (3) in Table 6. The results in the table support the inferences above with Figure 1. Consistent with German firms reducing their tax-induced earnings management with provisions after the BTR of 2008, the coefficient estimates on the interaction term, Treat $_{j} \times$ TPeriod $_{t}$, are negative and statistically significant at the 1 percent level or better in all columns. Given that provisions are not indicative of international income shifting across jurisdictions but are instead used with intertemporal shifting, this provides further support for our interpretation of the baseline findings in Table 4 as conforming tax avoidance. Overall, our baseline tests in Table 4 for domestic firms along with the combined analysis in all three sets of validation tests in the Tables 5 and 6 provide us reasonable assurance that our specifications with equation (1) enable us to investigate tax-induced earnings management behavior and that

\footnotetext{
${ }^{22}$ A concern could be that the German Balance Sheet Reform Act in 2009 ("Bilanzmodernisierungsgesetz 2009") might interfere with the implications of the German BTR of 2008. However, this adjustment of the German tax and financial accounting standards only had a minor effect on provisions. Apart from terminology aspects, the only relevant change was to reduce the required time from one year to a three month period for catching up with regards to the accounting for maintenance and repair operations when provisions are reported for neglected maintenance and repair operations in the current year. A more relevant change of the Balance Sheet Reform Act of 2009 was that it reduced book-tax conformity in German tax accounting regulations. The act allowed that accounting choices for German tax accounting could be made independently from accounting choices for German local GAAP. Before 2009, accounting choices had to be aligned in both systems. Thus, this can be viewed as additional empirical support for H1. Corresponding to H1, reducing the degree of book-tax conformity would also be expected to produce a lower degree of tax-induced earnings management. This is exactly what we find for the case of German provisions in Figure 1 and in Table 6.
} 
results with this specification are unlikely to be alternatively explained by international income shifting of MNEs.

\section{Tests on the association of book-tax conformity and tax-induced earnings}

\section{management}

Tables 7 and 8 present estimates of our equations (4) and (5) as tests of whether variation in book-tax conformity alters tax-induced earnings management (conforming tax avoidance) (H1). In the first test in Table 7, we interact a dummy variable for countries with an above-average level of book-tax conformity, BTaxC High, with Tax $_{j}$ Rate $_{j, t .}$. As BTaxC $\mathrm{High}_{j}$ varies exclusively at the country level, we do not include firm fixed effects or country fixed effects that require variation over time. In a second test on changes in book-tax conformity in Table 8, we interact Tax Rate $_{j, t}$ with a variable for significant changes in book-tax conformity (BTaxC Change $\left.e_{j, t}\right)$. BTaxC Change $e_{j, t}$ takes a value of one (minus one), if a country with a below-average (above-average) conformity level changes to above average (below-average) conformity from $t-1$ to $t$.

Consistent with $\mathrm{H} 1$, we find a negative coefficient estimate on the interaction term in all columns of Tables 7 and 8, indicating that higher conformity amplifies the negative association of the statutory tax rate and pre-tax book income. Specifically, for all subsamples (full sample, domestic sample, and MNE sample), both approaches (BTaxC High $_{j}$, BTaxC Change $e_{j, t}$ ), and both book-tax conformity measures (Watrin, Ebert, and Thomsen 2014; Tang 2015), we obtain a negative and statistically significant coefficient estimate on our interaction term of book-tax conformity and tax rates at least at the 10 percent level. ${ }^{23}$ In untabulated robustness tests, we also conduct analysis with an alternative

\footnotetext{
${ }^{23}$ Using the book-tax conformity measure of Watrin, Ebert, and Thomsen (2014) reduces the number of observations in Table 8 (changes of book-tax conformity) but not in Table 7 (levels of book-tax conformity) due to data limitations. With Amadeus, we are not able to calculate the measure for each country-year combination. Further, due to data limitations in the Compustat Global Fundamental file, we lose some observations in both Table 7 and Table 8 if we use the book-tax conformity measure of Tang (2015).
} 
book-tax conformity measure (Atwood, Drake, and Myers 2010). In spite of a reduced observation period due to data constraints, ${ }^{24}$ analyses in these tests confirm our finding that a higher level of book-tax conformity relates to additional tax-induced earnings management in both domestic and MNE firms. Overall, while prior literature shows that book-tax conformity mitigates nonconforming tax avoidance, results in Tables 7 and 8 suggest that higher levels of conformity may instead amplify this alternative, conforming tax avoidance behavior (tax-induced earnings management).

\section{CONCLUSION}

In this study, we identify and quantify tax-induced earnings management in an international context and investigate whether book-tax conformity alters this type of earnings management behavior. To do this, we first develop and validate a methodology for examining tax-induced earnings management (conforming tax avoidance) in this setting. In addition to allowing us to investigate the research question in our study, this methodology offers an avenue for future researchers interested in studying alternative factors that could influence conforming tax avoidance in an international setting.

Overall, results with our baseline tests using this methodology document that the manipulation of book earnings related to statutory tax rates is significant in terms of both statistical and economic magnitudes. Further, while prior literature predicts that one potential benefit of greater conformity could be curtailing nonconforming tax avoidance (Tang 2015), we provide evidence that one cost of greater conformity is additional taxinduced earnings management (conforming tax avoidance). This result is important because, unlike nonconforming tax avoidance, a reduction in tax liabilities (and, therefore, tax revenues) through conforming tax strategies can come with additional financial

\footnotetext{
${ }^{24}$ As mentioned before, if we use the book-tax conformity measure of Atwood, Drake, and Myers (2010), this requires the Compustat Legacy File that is only available until 2007. The data restrictions for this analysis reduce our full sample by approximately 70 percent.
} 
reporting costs. Further, it contrasts with prior literature that does not find significant evidence of an effect from a change in conformity on noncompliance with book-tax conforming transactions for Chinese firms (Chan, Lin, and Mo, 2010). 


\section{References}

Atkinson, J. and J.D. Houston. 2018. The intersection of new Sec. 451 and revenue recognition. The Tax Adviser (June 1). Available at:

https://www.thetaxadviser.com/issues/2018/jun/new-sec-451-revenuerecognition.html

Atwood, T.J., M.S. Drake, J.N. Myers, and L.A. Myers. 2012. Home country tax system characteristics and corporate tax avoidance: International Evidence. The Accounting Review 87(6): 1831-1860.

Atwood, T.J., M.S. Drake, and L.A. Myers. 2010. Book-tax conformity, earnings persistence and the association between earnings and future cash flows. Journal of Accounting and Economics 50(1): 111-125.

Badertscher, B., S. Katz, S.O. Rego, and R. Wilson. 2019. Conforming tax avoidance and capital market pressure. The Accounting Review Online Early.

Beuselinck C., S., Cascino, M., Deloof, and A. Vanstraelen. 2019. Earnings management within multinational corporations. The Accounting Review 94(4): 45-76.

Blaylock, B., F. Gaertner, and T. Shevlin. 2015. The association between book-tax conformity and earnings management. Review of Accounting Studies 20(1): 141-172.

Blaylock, B., F. Gaertner, and T. Shevlin. 2017. Book-tax conformity and capital structure. Review of Accounting Studies 22(2): 903-932.

Chan, K.H., K.Z. Lin, and P. Mo. 2010. Will a departure from tax-based accounting encourage tax noncompliance? Archival evidence from a transition economy. Journal of Accounting and Economics 50 (1): 58-73.

Chen, W., P. Hribar, and S. Melessa. 2018. Incorrect inferences when using residuals as dependent variables. Journal of Accounting Research 56(3): 751-796.

Cloyd, C.B., J. Pratt, and T. Stock. 1996. The use of financial accounting choice to support aggressive tax positions: Public and private firms. Journal of Accounting Research, 34(1): 23-43.

Desai, M. 2005. The degradation of reported corporate profits. Journal of Economic Perspectives 19(4): 171-192.

De Simone, L. 2016. Does a common set of accounting standards affect tax-motivated income shifting for multinational firms? Journal of Accounting and Economics 61(1): 145-165.

De Simone, L., K.J. Klassen, and J.K. Seidman. 2017. Unprofitable affiliates and income shifting behavior. The Accounting Review 92(3): 113-136.

Dobbins, L., S. Eichfelder, F. Hechtner, and J. Hundsdoerfer. 2018. Intertemporal income shifting around a large tax cut: The case of depreciations. Schmalenbach Business Review 70(4): 313-340.

Dyreng, S.D., M. Hanlon, and E. Maydew. 2008. Long-run corporate tax avoidance. The Accounting Review 83(1): 61-82.

Erickson, M., M. Hanlon, and E. Maydew. 2004. How much will firms pay for earnings that do not exist? Evidence of taxes paid on allegedly fraudulent earnings. The Accounting Review, 79(2): 387-408.

Feldstein, M. 1995. The effect of marginal tax rates on taxable income: A panel study of the 1986 tax reform act. Journal of Political Economy 103(1): 551-572.

Feldstein, M. 1999. Tax avoidance and the deadweight loss of the income tax. The Review of Economics and Statistics 81(4): 674-680.

Grubert, H. and J. Mutti. 1991. Taxes, tariffs and transfer pricing in multinational corporate decision making. The Review of Economics and Statistics 73(2): 285-293. 
Guenther, D.A. 1994. Earnings management in response to corporate tax rate changes: Evidence from the 1986 Tax Reform Act. The Accounting Review 69(1): 230-243.

Guenther, D.A., E. Maydew, and S. Nutter. 1997. Financial reporting, tax costs, and book-tax conformity. Journal of Accounting and Economics 23(3): 225-248.

Hanlon, M. and S. Heitzman. 2010. A review of tax research. Journal of Accounting and Economics 50(2-3): 127-178.

Hanlon, M., S.K. Laplante, and T. Shevlin. 2005. Evidence for the possible information loss of conforming book income and taxable income. The Journal of Law and Economics 48(2): 407-442.

Hanlon, M., E. Maydew, and T. Shevlin. 2008. An unintended consequence of book-tax conformity: A loss of earnings informativeness. Journal of Accounting and Economics 46(2-3): 294-311.

Hanlon, M. and E. Maydew. 2009. Book-tax conformity: Implications for multinational firms. National Tax Journal 62(1): 127-153.

Hanlon, M. and T. Shevlin. 2005. Book-tax conformity for corporate income: An introduction to the issues. In J.M. Poterba (Eds.). Tax policy and the economy (Vol. 19). Cambridge, MA: National Bureau of Economic Research: 101-134.

Hines, J.R. and E.M. Rice. 1994. Fiscal paradise: Foreign tax havens and American business. The Quarterly Journal of Economics 109(1): 149-182.

Huizinga, H. and L. Laeven. 2008. International profit shifting within multinationals: A multi-country perspective. Journal of Public Economics 92(5): 1164-1182.

Hundsdoerfer, J. and M. Jacob. 2019. Conforming tax planning and firms' cost behavior. Available at: https://papers.ssrn.com/sol3/papers.cfm?abstract_id=3430726.

Joint Committee on Taxation.2006. Present law and background relating to corporate tax reform: Issues of conforming book and tax income and capital cost recovery. Available at:

https://www.jct.gov/publications.html?func=startdown\&id=1504.

Klassen, K. 1997. The Impact of inside ownership concentration on the trade-off between financial and tax reporting. The Accounting Review 72(3): 455-474.

Klassen, K. and A. Mawani. 2000. The impact of financial and tax reporting incentives on option grants to Canadian CEOs. Contemporary Accounting Research 17(2): 227-262.

Kothari, S.P., A.J. Leone, and C.E. Weasley. 2005. Performance matched discretionary accruals measures. Journal of Accounting and Economics 39(1): 163-197.

KPMG. 2006. KPMG's corporate tax rate survey 2006, KPMG International, United Kingdom.

Leuz, C., D. Nanda, D., and P. Wysocki. 2003. Earnings management and investor protection: An international comparison. Journal of Financial Economics 29(1): 5372.

Markle, K. 2016. A comparison of the tax-motivated income shifting of multinationals in territorial and worldwide countries. Contemporary Accounting Research 33(1): 7-43.

Matsunaga, S., T. Shevlin, and D. Shores. 1992. Disqualifying dispositions of incentive stock options: Tax benefits versus financial reporting costs. Journal of Accounting Research 30(Supplement): 37-68.

Maydew, E. 1997. Tax-induced earnings management by firms with net operating losses. Journal of Accounting Research 35(1): 83-96.

Mills, L. and K. Newberry. 2001. The influence of tax and nontax costs on book-tax reporting differences: Public and private firms. The Journal of the American Taxation Association 23(1): 1-19. 
OECD (2009), A progress report on the jurisdictions surveyed by the OECD Global Forum in implementing the internationally agreed tax standard, Organization for Economic Cooperation and Development (OECD), Paris.

Penno, M. and D.T. Simon. 1986. Accounting choices: Public versus private firms. Journal of Business Finance \& Accounting 13(4): 561-569.

Roubi, R.R. and A.W. Richardson. 1998. Managing discretionary accruals in response to reductions in corporate tax rates in Canada, Malaysia and Singapore. International Journal of Accounting 33(4): 455-467.

Saez, E. 2010. Do taxpayers bunch at kink points? American Economic Journal: Economic Policy 2(3): 180-212.

Scholes, M.S., G.P. Wilson, and M.A. Wolfson. 1992. Firms' responses to anticipated reductions in tax rates: The tax reform act of 1986. Journal of Accounting Research 30(Supplement): 161-185.

Tang, T. 2015. Does book-tax conformity deter opportunistic book and tax reporting? An international analysis. European Accounting Review 24(3): 441-469.

Watrin, C., N. Ebert, and M. Thomsen. 2014. Book-tax conformity and earnings management: Insights from European one- and two-book systems. Journal of the American Taxation Association 36(2): 55-89. 


\section{Appendix 1: Variable Definitions}

\begin{tabular}{|c|c|c|}
\hline Variable & Definition & Data Source \\
\hline \multicolumn{3}{|l|}{ Dependent variables } \\
\hline $\log P T I_{i, t}$ & Logarithm of the pre-tax income of an entity $i$ in thousands of U.S. dollars. & Amadeus \\
\hline \multicolumn{3}{|l|}{ Tax variables } \\
\hline$\overline{\text { Tax Rate }_{j, t}}$ & $\begin{array}{l}\text { The maximum statutory corporate income tax rate of entity } i \text { 's country } j \\
\text { including average local and state income taxes. }\end{array}$ & KPMG \\
\hline$B \operatorname{Tax} C_{j, t}$ & $\begin{array}{l}\text { Book-tax conformity of entity } i \text { 's country } j \text {, measured by a scaled ranking of } \\
\text { countries }(0=\text { low book-tax conformity, } 1=\text { high book-tax conformity). } \\
\text { These measures are obtained from Watrin, Ebert, and Thomsen (2014) and } \\
\text { Tang (2015). For the calculation of the measure of Tang (2015), we rely on } \\
\text { the Compustat Global Fundamental file from } 2005 \text { to } 2013 \text {, while we use } \\
\text { Amadeus data from the same period to calculate the measure of Watrin, } \\
\text { Ebert, and Thomsen (2014). We provide a detailed discussion on the } \\
\text { calculation of these measures in Appendix } 3 \text {. }\end{array}$ & $\begin{array}{l}\text { Compustat Global } \\
\text { Fundamentals / } \\
\text { Amadeus }\end{array}$ \\
\hline BTaxC High & $\begin{array}{l}\text { This is a dummy variable with a value of one if the average level of } \\
\text { BTax } C_{j, t, \text { in a country } j \text { for the observation period (2005-2013) exceeds the }} \\
\text { average level of } \operatorname{BTax}_{j, t,} \text { across all countries. }\end{array}$ & $\begin{array}{l}\text { Compustat Global } \\
\text { Fundamentals / } \\
\text { Amadeus }\end{array}$ \\
\hline BTaxC Change $e_{j, t}$ & $\begin{array}{l}\text { The variable indicates a significant increase in } B \operatorname{Tax} C_{j, t,} \text { by }+1 \text {, a significant } \\
\text { decrease in } B \operatorname{Tax} C_{j, t,} \text { by }-1 \text {, and a year without a significant change as } 0 . \\
\text { Increases and decreases are significant if they raise (reduce) the level of } \\
B T a x C_{j, t} \text { to above (below) the average level of } B \operatorname{Bax} C_{j, t,} \text {, in the current } \\
\text { sample year. }\end{array}$ & $\begin{array}{l}\text { Compustat Global } \\
\text { Fundamentals / } \\
\text { Amadeus }\end{array}$ \\
\hline \multicolumn{3}{|c|}{ Firm level control variables } \\
\hline Log Compensation $_{i, t}$ & $\begin{array}{l}\text { Logarithm of entity } i \text { 's employee compensation costs, measured in } \\
\text { thousands of U.S. dollars. }\end{array}$ & Amadeus \\
\hline Log Assets $_{i, t}$ & $\begin{array}{l}\text { Logarithm of an entity } i \text { 's total assets, measured in thousands of U.S. } \\
\text { dollars. }\end{array}$ & Amadeus \\
\hline Parent & Dummy variable with a value of one if entity $i$ is a parent firm. & Amadeus \\
\hline Public & Dummy variable with a value of one if entity $i$ is a publicly listed firm. & Amadeus \\
\hline \multicolumn{3}{|c|}{ Country level control variables } \\
\hline $\log G D P_{j, t}$ & $\begin{array}{l}\text { Gross domestic product of an entity } i \text { 's host country } j \text { in billions of U.S. } \\
\text { dollars. }\end{array}$ & World Bank \\
\hline Log GDP per Capita ${ }_{j, t}$ & $\begin{array}{l}\text { Gross domestic product of an entity } i \text { 's host country } j \text { per capita in } \\
\text { thousands of U.S. dollars. }\end{array}$ & World Bank \\
\hline
\end{tabular}




\section{Appendix 2: List of Tax Haven jurisdictions}

In OECD (2009), the following jurisdictions are mentioned as a tax haven:

Andorra

Anguilla

Antigua and Barbuda

Aruba

Bahamas

Bahrain

Belize

Bermuda

British Virgin Islands

Cayman Islands

Cook Islands

Dominica

Gibraltar

Grenada

Liberia

Liechtenstein
Marshall Islands

Monaco

Montserrat

Nauru

Netherlands

Antilles

Niue

Panama

St Kitts and Nevis

St Lucia

St Vincent \& Grenadines

Samoa

San Marino

Turks and Caicos Islands

Vanuatu 


\section{Appendix 3: Calculation of book-tax conformity measures}

Following Watrin, Ebert, and Thomsen (2014), we define book-tax conformity based on the average descending rank of a continuous variable across our analysis period. Watrin, Ebert, and Thomsen (2014) measure book-tax conformity as an aggregation by country-year of the absolute value of an entity's permanent book-tax differences $\left(\right.$ PermBTD $\left._{i, t,}\right)$ scaled by lagged total assets. We calculate the permanent book-tax difference as follows:

$\operatorname{PermBTD}_{i, t}=P T B I_{i, t}-\frac{\operatorname{TAX}_{i, t}}{\text { Tax Rate }_{j, t}}$

using pre-tax book income $P T B I_{i, t}$, the total tax expense $T A X A_{i, t}$, and the country's

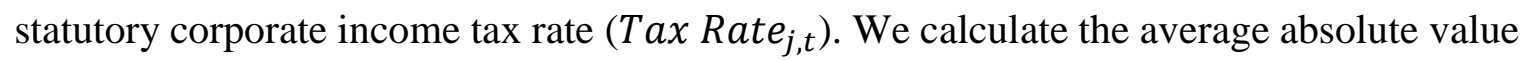
of PermBTD $D_{i, t}$ by country-year. A higher (lower) aggregate, absolute value of permanent BTDs $\left(\right.$ PermBTD $\left._{i, t}\right)$ is expected to represent lower (higher) book-tax conformity. We then rank countries within a given year in descending order based on their $\operatorname{PermBTD}_{i, t}$ and scale the ranking within each year so that values range from zero to one. Ranking in descending order ensures that lower values near zero represent the lowest conformity and higher values near one represent the highest conformity for ease of interpreting the created variable as increasing in book-tax conformity. We then use the average scaled ranking of a country within the observation period to define book-tax conformity for our analysis.

Following Tang (2015), we alternatively calculate book-tax conformity by estimating the root mean squared error (RMSE) from the following equation, estimated by country-year. Different from the measure of Watrin, Ebert, and Thomsen (2014), this measure is calculated with consolidated data at the level of firm groups $g$ using the Compustat Global Fundamental file:

$$
B T D_{g, t}=\Upsilon_{0}+\Upsilon_{1} D A C C_{g, t}+\Upsilon_{2} T P_{g, t}+\Upsilon_{3} D A C C \times T P_{g, t}+u_{g, t}
$$


$B T D_{g, t}$ are the book-tax differences at the consolidated (GUO $g$ ) level in year $t$, calculated as pre-tax book income multiplied by the statutory tax rate less current tax expenses, that are scaled by total assets. $D A C C_{g, t}$ are the discretionary accruals that are calculated by a modified Jones model with lagged return-on-assets by country for each industry as documented by Kothari, Leone and Weasley (2005). These discretionary accruals are used as a control variable to account for earnings management activities at the firm level. $T P_{g, t}$ is a control variable for tax avoidance activities at the firm level. It is calculated by the difference of the statutory tax rate STR and the current effective tax rate CETR (i.e., the ratio of current tax expense to operating cash flows), which is truncated in a range from 0 to 1 . We winsorize scaled book-tax differences at the $1^{\text {st }}$ and the $99^{\text {th }}$ percentiles. Slightly different from Tang (2015), we use the Compustat Global Fundamental file from 2005 to 2013 for estimation. ${ }^{25}$

After estimating the RMSE by country-year, where higher (lower) RMSE is assessed as a lower (higher) degree of book-tax conformity, we follow Tang (2015) and rank countries within a given year in descending order based on their RMSE and scale the ranking within each year so that values range from zero to one. Therefore, by again using a descending rank of this continuous variable and scaling the ranking within each year to range between zero and one, values near zero represent lower conformity and values near one represent higher conformity.

\footnotetext{
${ }^{25}$ Tang (2015) uses the Compustat Global Industrial/Commercial files from 1994 to 2007 for estimation.
} 
Figures and Tables

Figure 1: Graphical analysis: Impact of the German BTR 2008 on provisions

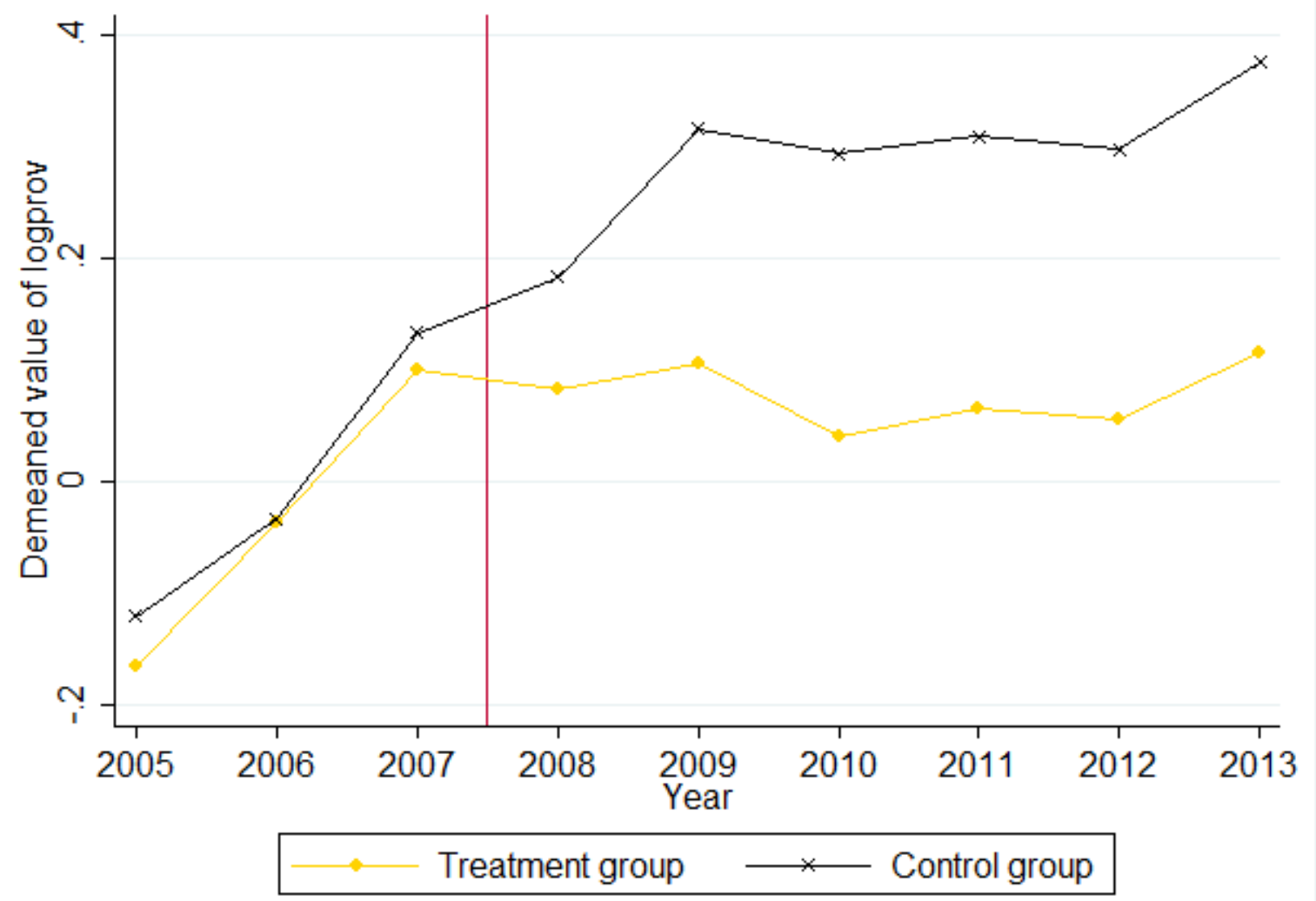


Table 1: Sample construction and country-level composition

\begin{tabular}{|c|c|c|c|c|c|c|}
\hline \multicolumn{7}{|l|}{ Panel A: Sample selection } \\
\hline \multirow[b]{2}{*}{ Selection process } & \multicolumn{2}{|c|}{ Parents } & \multicolumn{2}{|c|}{ Subsidiaries } & \multicolumn{2}{|c|}{ Total } \\
\hline & Firms & Obs. & Firms & Obs. & Firms & Obs. \\
\hline Firms identified & 331,431 & & $1,237,525$ & & $1,568,956$ & \\
\hline Residence in EU-28 & 331,431 & & $1,062,510$ & & $1,393,941$ & \\
\hline Data available & 303,348 & & 770,840 & & $1,074,188$ & \\
\hline Active firms & 303,348 & & 759,848 & & $1,063,196$ & \\
\hline No financial institution/insurance & 169,164 & & 543,533 & & 712,697 & \\
\hline Not parent \& subsidiary & 155,038 & & 533,296 & & 688,334 & \\
\hline Reliable MNE status & 141,244 & & 433,591 & & 575,835 & \\
\hline Complete accounting data & 53,406 & 307,578 & 118,408 & 607,237 & 171,814 & 914,815 \\
\hline Tax planning incentive & 45,422 & 214,463 & 94,793 & 398,305 & 140,215 & 612,768 \\
\hline Local GAAP statements & 42,046 & 175,357 & 90,138 & 354,482 & 132,184 & 529,840 \\
\hline Global ultimate owner & 41,890 & 174,760 & 81,424 & 324,377 & 123,314 & 499,137 \\
\hline No micro firms & 36,527 & 148,794 & 72,999 & 297,343 & 109,526 & 446,137 \\
\hline Sufficient observations per cluster & 34,811 & 142,667 & 69,220 & 283,926 & 104,031 & 426,593 \\
\hline Total & 34,811 & 142,667 & 69,220 & 283,926 & 104,031 & 426,593 \\
\hline \multicolumn{7}{|c|}{$\begin{array}{l}\text { 'Firms identified': Amadeus database has been searched for active firms in an EU-28 country that are marked as global } \\
\text { ultimate owner (GUO); subsidiaries are all firms that are recorded in Amadeus as a subsidiary of the GUO up to the } 10^{\text {th }} \\
\text { level. 'Residence in EU-28': Affiliates were dropped if resident outside EU-28. 'Data available': Firms were dropped } \\
\text { if AMADEUS does not provide the firm's company, accounting or status data. 'Active firms': entity observations were } \\
\text { dropped if not marked as 'active' (e.g., due to bankruptcy, insolvency). 'No financial institutions/insurances': Firms } \\
\text { with 2-digit NACE codes } 64,65 \text { or } 66 \text { are excluded. 'Not parent \& subsidiary': Entities are dropped if they are a parent } \\
\text { as well as a subsidiary. 'Reliable MNE status': A firm is classified as a domestic firm if no relationship to a foreign firm } \\
\text { is identified. A firm is categorized as MNE firm if either the parent or another majority owned group entity is resident } \\
\text { abroad. All other firms are excluded. 'Complete accounting information': Observations are excluded if financial } \\
\text { statement data is incomplete or implausible (e.g. negative fixed assets, total assets or employee costs). Additionally, } \\
\text { observations are excluded if the reporting period does not equal } 12 \text { months, as the analysis also uses flow figures that } \\
\text { are depending on the length of the reporting period. 'Tax planning incentive': Only public and private limited companies } \\
\text { are included. All other legal forms are dropped (e.g., nonprofit organizations, public authorities). 'Local GAAP } \\
\text { statements': IFRS statements are excluded. 'Global ultimate owner': The global ultimate owner (GUO, respectively the } \\
\text { parent) can be identified and has a minimum shareholding of more than 50\%; firms without a majority global ultimate } \\
\text { owner or inconsistent data on the GUO (including foreign GUOs) are excluded. 'No micro firms': We exclude all firm } \\
\text { observations with total assets below } \$ 500,000 \text {. 'Sufficient observations per cluster': We exclude observations in } \\
\text { country-industry combinations (based on one-digit SIC codes) that do not have at least } 30 \text { observations. }\end{array}$} \\
\hline \multicolumn{7}{|c|}{ Panel B: Observations by country and MNE status } \\
\hline Country & & mestic & & MNE & & Total \\
\hline Austria & & 133 & & 2,202 & & 2,335 \\
\hline Belgium & & 47,626 & & 23,809 & & 71,435 \\
\hline Bulgaria & & 3,539 & & 1,579 & & 5,118 \\
\hline Croatia & & 329 & & 1,959 & & 2,288 \\
\hline Czech Republic & & 8,895 & & 10,787 & & 19,682 \\
\hline Denmark & & 13,394 & & 5,962 & & 19,356 \\
\hline Estonia & & 829 & & 2,000 & & 2,829 \\
\hline Finland & & 8,139 & & 7,264 & & 15,403 \\
\hline France & & 18,462 & & 31,816 & & 50,278 \\
\hline Germany & & 12,781 & & 22,558 & & 35,339 \\
\hline Hungary & & 0 & & 2,583 & & 2,583 \\
\hline Ireland & & 301 & & 152 & & 453 \\
\hline Italy & & 20,931 & & 29,166 & & 50,097 \\
\hline Luxembourg & & 0 & & 159 & & 159 \\
\hline Netherlands & & 7,144 & & 4,201 & & 11,345 \\
\hline Poland & & 3,771 & & 5,077 & & 8,848 \\
\hline Portugal & & 3,041 & & 4,449 & & 7,490 \\
\hline Romania & & 2,635 & & 5,749 & & 8,384 \\
\hline Slovakia & & 1,486 & & 4,280 & & 5,766 \\
\hline Slovenia & & 416 & & 1,582 & & 1,998 \\
\hline Spain & & 8,201 & & 7,252 & & 15,453 \\
\hline Sweden & & 26,097 & & 9,423 & & 35,520 \\
\hline United Kingdom & & 23,747 & & 30,687 & & 54,434 \\
\hline Total & & 11,897 & & 14,696 & & 426,593 \\
\hline
\end{tabular}


Table 2: Tax rates per country and year

\begin{tabular}{|c|c|c|c|c|c|c|c|c|c|}
\hline Country & 2005 & 2006 & 2007 & 2008 & 2009 & 2010 & 2011 & 2012 & 2013 \\
\hline Austria & $25.00 \%$ & $25.00 \%$ & $25.00 \%$ & $25.00 \%$ & $25.00 \%$ & $25.00 \%$ & $25.00 \%$ & $25.00 \%$ & $25.00 \%$ \\
\hline Belgium & $33.99 \%$ & $33.99 \%$ & $33.99 \%$ & $33.99 \%$ & $33.99 \%$ & $33.99 \%$ & $33.99 \%$ & $33.99 \%$ & $33.99 \%$ \\
\hline Bulgaria & $15.00 \%$ & $15.00 \%$ & $10.00 \%$ & $10.00 \%$ & $10.00 \%$ & $10.00 \%$ & $10.00 \%$ & $10.00 \%$ & $10.00 \%$ \\
\hline Croatia & $20.32 \%$ & $20.00 \%$ & $20.00 \%$ & $20.00 \%$ & $20.00 \%$ & $20.00 \%$ & $20.00 \%$ & $20.00 \%$ & $20.00 \%$ \\
\hline Czech Republic & $26.00 \%$ & $24.00 \%$ & $24.00 \%$ & $21.00 \%$ & $20.00 \%$ & $19.00 \%$ & $19.00 \%$ & $19.00 \%$ & $19.00 \%$ \\
\hline Denmark & $28.00 \%$ & $28.00 \%$ & $25.00 \%$ & $25.00 \%$ & $25.00 \%$ & $25.00 \%$ & $25.00 \%$ & $25.00 \%$ & $25.00 \%$ \\
\hline Estonia & $24.00 \%$ & $23.00 \%$ & $22.00 \%$ & $21.00 \%$ & $21.00 \%$ & $21.00 \%$ & $21.00 \%$ & $21.00 \%$ & $21.00 \%$ \\
\hline Finland & $26.00 \%$ & $26.00 \%$ & $26.00 \%$ & $26.00 \%$ & $26.00 \%$ & $26.00 \%$ & $26.00 \%$ & $24.50 \%$ & $24.50 \%$ \\
\hline France & $33.83 \%$ & $33.33 \%$ & $33.33 \%$ & $33.33 \%$ & $33.33 \%$ & $33.33 \%$ & $33.33 \%$ & $33.33 \%$ & $33.33 \%$ \\
\hline Germany & $38.31 \%$ & $38.34 \%$ & $38.36 \%$ & $29.51 \%$ & $29.44 \%$ & $29.41 \%$ & $29.37 \%$ & $29.48 \%$ & $29.55 \%$ \\
\hline Hungary & $16.00 \%$ & $16.00 \%$ & $16.00 \%$ & $16.00 \%$ & $16.00 \%$ & $19.00 \%$ & $19.00 \%$ & $19.00 \%$ & $19.00 \%$ \\
\hline Ireland & $12.50 \%$ & $12.50 \%$ & $12.50 \%$ & $12.50 \%$ & $12.50 \%$ & $12.50 \%$ & $12.50 \%$ & $12.50 \%$ & $12.50 \%$ \\
\hline Italy & $37.25 \%$ & $37.25 \%$ & $37.25 \%$ & $31.40 \%$ & $31.40 \%$ & $31.40 \%$ & $31.40 \%$ & $31.40 \%$ & $31.40 \%$ \\
\hline Luxembourg & $30.38 \%$ & $29.63 \%$ & $29.63 \%$ & $29.63 \%$ & $28.59 \%$ & $28.59 \%$ & $28.80 \%$ & $28.80 \%$ & $29.22 \%$ \\
\hline Netherlands & $31.50 \%$ & $29.60 \%$ & $25.50 \%$ & $25.50 \%$ & $25.50 \%$ & $25.50 \%$ & $25.00 \%$ & $25.00 \%$ & $25.00 \%$ \\
\hline Poland & $19.00 \%$ & $19.00 \%$ & $19.00 \%$ & $19.00 \%$ & $19.00 \%$ & $19.00 \%$ & $19.00 \%$ & $19.00 \%$ & $19.00 \%$ \\
\hline Portugal & $27.50 \%$ & $27.50 \%$ & $25.00 \%$ & $25.00 \%$ & $25.00 \%$ & $25.00 \%$ & $25.00 \%$ & $25.00 \%$ & $25.00 \%$ \\
\hline Romania & $16.00 \%$ & $16.00 \%$ & $16.00 \%$ & $16.00 \%$ & $16.00 \%$ & $16.00 \%$ & $16.00 \%$ & $16.00 \%$ & $16.00 \%$ \\
\hline Slovakia & $19.00 \%$ & $19.00 \%$ & $19.00 \%$ & $19.00 \%$ & $19.00 \%$ & $19.00 \%$ & $19.00 \%$ & $19.00 \%$ & $23.00 \%$ \\
\hline Slovenia & $25.00 \%$ & $25.00 \%$ & $23.00 \%$ & $22.00 \%$ & $21.00 \%$ & $20.00 \%$ & $20.00 \%$ & $18.00 \%$ & $17.00 \%$ \\
\hline Spain & $35.00 \%$ & $35.00 \%$ & $32.50 \%$ & $30.00 \%$ & $30.00 \%$ & $30.00 \%$ & $30.00 \%$ & $30.00 \%$ & $30.00 \%$ \\
\hline Sweden & $28.00 \%$ & $28.00 \%$ & $28.00 \%$ & $28.00 \%$ & $26.30 \%$ & $26.30 \%$ & $26.30 \%$ & $26.30 \%$ & $22.00 \%$ \\
\hline United Kingdom & $30.00 \%$ & $30.00 \%$ & $30.00 \%$ & $30.00 \%$ & $28.00 \%$ & $28.00 \%$ & $26.00 \%$ & $24.00 \%$ & $23.00 \%$ \\
\hline
\end{tabular}


Table 3: Descriptive statistics

\begin{tabular}{|c|c|c|c|c|c|c|}
\hline Variables & Obs. & Mean & Median & St. Dev. & Min. & Max. \\
\hline \multicolumn{7}{|l|}{ Panel A: Total sample } \\
\hline Pre-tax book income ${ }^{\mathrm{a}}$ & 426,593 & 3,674 & 404 & 53,557 & 0.00129 & $17,032,864$ \\
\hline Total assets ${ }^{\mathrm{a}}$ & 426,593 & 40,928 & 5,611 & 417,774 & 500 & $51,298,912$ \\
\hline Total compensation $^{\mathrm{a}}$ & 426,593 & 6,540 & 1,263 & 56,029 & 0.00129 & $12,261,405$ \\
\hline Statutory tax rate ${ }^{b}$ & 426,593 & 28.98 & 30.00 & 5.66 & 10.00 & 38.36 \\
\hline $\mathrm{GDP}^{\mathrm{c}}$ & 426,593 & 1,430 & 836 & 1,169 & 14 & 3,757 \\
\hline GDP per capita ${ }^{a}$ & 426,593 & 39.28 & 41.63 & 12.49 & 3.85 & 113.73 \\
\hline \multicolumn{7}{|c|}{ Panel B: Domestic subsample } \\
\hline Pre-tax book income ${ }^{\mathrm{a}}$ & 211,897 & 750 & 219 & 7,134 & 0.00129 & $2,988,631$ \\
\hline Total assets ${ }^{\mathrm{a}}$ & 211,897 & 9,044 & 3,180 & 51,953 & 500 & $6,877,572$ \\
\hline Total compensation ${ }^{\mathrm{a}}$ & 211,897 & 2,123 & 713 & 6,528 & 0.00129 & 893,040 \\
\hline Statutory tax rate ${ }^{b}$ & 211,897 & 29.09 & 30.00 & 5.50 & 10.00 & 38.36 \\
\hline $\mathrm{GDP}^{\mathrm{c}}$ & 211,897 & 1,246 & 527 & 1,101 & 14 & 3,757 \\
\hline GDP per capita ${ }^{a}$ & 211,897 & 41.21 & 43.09 & 12.24 & 3.85 & 64.18 \\
\hline \multicolumn{7}{|c|}{ Panel C: MNE subsample } \\
\hline Pre-tax book income ${ }^{a}$ & 214,696 & 6,560 & 810 & 75,049 & 0.0216 & $17,032,864$ \\
\hline Total assets ${ }^{\mathrm{a}}$ & 214,696 & 72,397 & 9,927 & 584,926 & 500 & $51,298,912$ \\
\hline Total compensation $^{\mathrm{a}}$ & 214,696 & 10,900 & 2,333 & 78,468 & 0.0185 & $12,261,405$ \\
\hline Statutory tax rate ${ }^{b}$ & 214,696 & 28.86 & 30.00 & 5.80 & 10.00 & 38.36 \\
\hline $\mathrm{GDP}^{\mathrm{c}}$ & 214,696 & 1,611 & 2,075 & 1,205 & 14 & 3,757 \\
\hline GDP per capita ${ }^{a}$ & 214,696 & 37.37 & 40.85 & 12.45 & 3.85 & 113.73 \\
\hline
\end{tabular}

Notes: ${ }^{a}$ In thousands of U.S. dollars, using current prices.

${ }^{\mathrm{b}}$ Top statutory corporate tax rates in percent including average local taxes and surtaxes.

${ }^{\mathrm{c}}$ In billions of U.S. dollars, using current prices. 
Table 4: Baseline tests: Regression of pre-tax book income on tax rates

\begin{tabular}{|c|c|c|c|c|c|c|}
\hline \multirow{2}{*}{$\begin{array}{l}\text { Dependent variable } \\
\text { Sample }\end{array}$} & \multicolumn{6}{|c|}{$\log P T I$} \\
\hline & $\begin{array}{l}\text { All } \\
\text { (1) }\end{array}$ & $\begin{array}{c}\text { Domestic } \\
\text { (2) }\end{array}$ & $\begin{array}{c}\text { MNE } \\
\text { (3) }\end{array}$ & $\begin{array}{l}\text { All } \\
(4)\end{array}$ & $\begin{array}{c}\text { Domestic } \\
\text { (5) }\end{array}$ & $\begin{array}{c}\text { MNE } \\
\text { (6) }\end{array}$ \\
\hline Tax Rate & $\begin{array}{c}-0.860 * * * \\
(-3.271)\end{array}$ & $\begin{array}{c}-0.972 * * * \\
(-2.940)\end{array}$ & $\begin{array}{c}-0.745 * * \\
(-2.474)\end{array}$ & $\begin{array}{c}-0.793 * * * \\
(-3.285)\end{array}$ & $\begin{array}{c}-1.257 * * * \\
(-4.056)\end{array}$ & $\begin{array}{l}-0.521 * \\
(-1.872)\end{array}$ \\
\hline Log Assets & $\begin{array}{c}0.706 * * * \\
(57.282)\end{array}$ & $\begin{array}{c}0.752 * * * \\
(35.212)\end{array}$ & $\begin{array}{c}0.667 * * * \\
(47.834)\end{array}$ & $\begin{array}{l}0.774 * * * \\
(110.689)\end{array}$ & $\begin{array}{c}0.765 * * * \\
(69.768)\end{array}$ & $\begin{array}{c}0.755 * * * \\
(93.676)\end{array}$ \\
\hline Log Compensation & $\begin{array}{c}0.156^{* * *} * \\
(14.993)\end{array}$ & $\begin{array}{c}0.118 * * * \\
(9.368)\end{array}$ & $\begin{array}{c}0.199 * * * \\
(15.025)\end{array}$ & $\begin{array}{c}0.162 * * * \\
(24.710)\end{array}$ & $\begin{array}{c}0.136 * * * \\
(16.507)\end{array}$ & $\begin{array}{c}0.181 * * * \\
(23.169)\end{array}$ \\
\hline $\log G D P$ & $\begin{array}{c}2.161 * * * \\
(4.582)\end{array}$ & $\begin{array}{c}3.780 * * * \\
(6.181)\end{array}$ & $\begin{array}{c}1.275 * * \\
(2.327)\end{array}$ & $\begin{array}{c}1.959 * * * \\
(4.784)\end{array}$ & $\begin{array}{c}3.367 * * * \\
(6.153)\end{array}$ & $\begin{array}{c}0.954 * * \\
(2.027)\end{array}$ \\
\hline Log GDP per capita & $\begin{array}{c}-2.170 * * * \\
(-4.591)\end{array}$ & $\begin{array}{c}-3.493 * * * \\
(-5.699)\end{array}$ & $\begin{array}{c}-1.524 * * * \\
(-2.854)\end{array}$ & $\begin{array}{c}-1.967 * * * \\
(-4.867)\end{array}$ & $\begin{array}{c}-3.083 * * * \\
(-5.646)\end{array}$ & $\begin{array}{c}-1.229 * * * \\
(-2.699)\end{array}$ \\
\hline Parent & & & & $\begin{array}{c}-0.211 * * * \\
(-14.808)\end{array}$ & $\begin{array}{c}-0.145^{* * *} \\
(-7.053)\end{array}$ & $\begin{array}{c}-0.157 * * * \\
(-7.253)\end{array}$ \\
\hline Public & & & & $\begin{array}{c}0.213 * * * \\
(14.977)\end{array}$ & $\begin{array}{c}-0.099 \\
(-1.130) \\
\end{array}$ & $\begin{array}{c}0.150 * * * \\
(10.677)\end{array}$ \\
\hline Firm fixed effects & $\sqrt{ }$ & $\sqrt{ }$ & $\sqrt{ }$ & & & \\
\hline Country fixed effects & & & & $\sqrt{ }$ & $\sqrt{ }$ & $\sqrt{ }$ \\
\hline Industry fixed effects & & & & $\sqrt{ }$ & $\sqrt{ }$ & $\sqrt{ }$ \\
\hline Year fixed effects & $\sqrt{ }$ & $\sqrt{ }$ & $\sqrt{ }$ & $\sqrt{ }$ & $\sqrt{ }$ & $\sqrt{ }$ \\
\hline Observations & 426,593 & 211,897 & 214,696 & 426,593 & 211,897 & 214,696 \\
\hline Number of firms & 104,031 & 53,284 & 50,747 & 104,031 & 53,284 & 50,747 \\
\hline $\mathrm{R}^{2}$ & 0.850 & 0.788 & 0.859 & 0.608 & 0.453 & 0.629 \\
\hline $\begin{array}{l}\text { Table } 4 \text { reports coeff } \\
\text { avoidance analysis in } \\
\text { level, with industry ba } \\
\text { entity in our sample. } \\
10 \%, 5 \% \text {, and } 1 \% \text { leve }\end{array}$ & $\begin{array}{l}\text { it estimates } \\
\text { ation (1). Th } \\
\text { on one-digit } \\
\text { rovide varial } \\
\text { espectively. }\end{array}$ & $\begin{array}{l}\text { nd t statisti } \\
\text { standard er } \\
\text { SIC codes. T } \\
\text { le definition }\end{array}$ & $\begin{array}{l}\text { (in paren } \\
\text { ors are robı } \\
\text { e firm fixe } \\
\text { in Appendi }\end{array}$ & $\begin{array}{l}\text { es) for ou } \\
\text { and cluster } \\
\text { ffects consi } \\
*, * * \text {, and }\end{array}$ & $\begin{array}{l}\text { aseline } \mathrm{c} \\
\text { at the co } \\
\mathrm{r} \text { a fixed } \\
* \text { denote }\end{array}$ & $\begin{array}{l}\text { forming tax } \\
\text { try-industry } \\
\text { ect for eacl } \\
\text { nificance a }\end{array}$ \\
\hline
\end{tabular}


Table 5: Validation tests: Evaluating income-shifting as an alternative explanation

\begin{tabular}{|c|c|c|c|c|c|c|}
\hline \multirow{3}{*}{$\begin{array}{l}\text { Dependent variable: } \\
\text { Test } \\
\text { Sample }\end{array}$} & \multicolumn{6}{|c|}{$\log P T I$} \\
\hline & \multicolumn{2}{|c|}{ Control for group profit } & \multicolumn{2}{|c|}{ Exclusion of Haven MNEs } & \multicolumn{2}{|c|}{ Public versus Private Firms } \\
\hline & $\begin{array}{l}\text { All } \\
\text { (1) }\end{array}$ & $\begin{array}{c}\text { MNE } \\
\text { (2) }\end{array}$ & $\begin{array}{l}\text { All } \\
\text { (3) }\end{array}$ & $\begin{array}{c}\text { MNE } \\
\text { (4) }\end{array}$ & $\begin{array}{l}\text { All } \\
\text { (5) }\end{array}$ & $\begin{array}{c}\text { MNE } \\
\text { (6) }\end{array}$ \\
\hline Tax Rate & $\begin{array}{c}-0.832 * * * * \\
(-3.139)\end{array}$ & $\begin{array}{c}-0.613 * * \\
(-2.000)\end{array}$ & $\begin{array}{c}-0.877 * * * \\
(-3.201)\end{array}$ & $\begin{array}{c}-0.745 * * \\
(-2.280)\end{array}$ & $\begin{array}{c}-0.879 * * * \\
(-3.609)\end{array}$ & $\begin{array}{c}-0.660 * * \\
(-2.439)\end{array}$ \\
\hline Tax Rate $\times$ Public & & & & & $\begin{array}{c}0.463 * * \\
(2.161)\end{array}$ & $\begin{array}{c}0.438 * * \\
(1.995)\end{array}$ \\
\hline Log Assets & $\begin{array}{c}0.698 * * * \\
(51.919)\end{array}$ & $\begin{array}{c}0.641 * * * \\
(42.547)\end{array}$ & $\begin{array}{c}0.719 * * * \\
(51.961)\end{array}$ & $\begin{array}{c}0.680 * * * \\
(39.080)\end{array}$ & $\begin{array}{l}0.774 * * * \\
(110.778)\end{array}$ & $\begin{array}{c}0.755 * * * \\
(93.861)\end{array}$ \\
\hline Log Compensation & $\begin{array}{c}0.152 * * * \\
(13.709)\end{array}$ & $\begin{array}{c}0.209 * * * \\
(14.228)\end{array}$ & $\begin{array}{c}0.149 * * * \\
(13.468)\end{array}$ & $\begin{array}{c}0.190^{* * * *} \\
(12.244)\end{array}$ & $\begin{array}{c}0.162 * * * \\
(24.714)\end{array}$ & $\begin{array}{r}0.181 * * * \\
(23.199)\end{array}$ \\
\hline Log Group Profit & $\begin{array}{c}0.053 * * * \\
(13.650)\end{array}$ & $\begin{array}{c}0.054 * * * \\
(13.411)\end{array}$ & & & & \\
\hline $\log G D P$ & $\begin{array}{c}2.388 * * * \\
(5.062)\end{array}$ & $\begin{array}{c}1.468 * * * \\
(2.643)\end{array}$ & $\begin{array}{c}2.316 * * * \\
(4.577)\end{array}$ & $\begin{array}{l}1.323 * * \\
(2.134)\end{array}$ & $\begin{array}{c}1.960 * * * \\
(4.788)\end{array}$ & $\begin{array}{c}0.977 * * \\
(2.067)\end{array}$ \\
\hline Log GDP per Capita & $\begin{array}{c}-2.337 * * * \\
(-4.932)\end{array}$ & $\begin{array}{c}-1.678 * * * \\
(-3.101)\end{array}$ & $\begin{array}{c}-2.311 * * * \\
(-4.533)\end{array}$ & $\begin{array}{c}-1.629 * * * \\
(-2.673)\end{array}$ & $\begin{array}{c}-1.973 * * * \\
(-4.882)\end{array}$ & $\begin{array}{c}-1.258 * * * \\
(-2.751)\end{array}$ \\
\hline Parent & & & & & $\begin{array}{c}-0.211 * * * \\
(-14.806)\end{array}$ & $\begin{array}{c}-0.156^{* * *} \\
(-7.253)\end{array}$ \\
\hline Public & & & & & $\begin{array}{c}-0.080 \\
(-1.302)\end{array}$ & $\begin{array}{c}-0.024 \\
(-0.392)\end{array}$ \\
\hline Firm fixed effects & $\sqrt{ }$ & $\sqrt{ }$ & $\sqrt{ }$ & $\sqrt{ }$ & & \\
\hline Country fixed effects & & & & & $\sqrt{ }$ & $\sqrt{ }$ \\
\hline Industry fixed effects & & & & & $\sqrt{ }$ & $\sqrt{ }$ \\
\hline Year fixed effects & $\sqrt{ }$ & $\sqrt{ }$ & $\sqrt{ }$ & $\sqrt{ }$ & $\sqrt{ }$ & $\sqrt{ }$ \\
\hline Observations & 370,078 & 155,824 & 378,335 & 164,855 & 426,593 & 214,696 \\
\hline Number of firms & 93,206 & 39,098 & 92,790 & 39,020 & 104,031 & 50,747 \\
\hline $\mathrm{R}^{2}$ & 0.857 & 0.885 & 0.834 & 0.845 & 0.606 & 0.629 \\
\hline $\begin{array}{l}\text { Columns (1)-(4) of } \mathrm{T} \\
\text { alternative explanatior } \\
\text { of equation (2) as a v } \\
\text { robust and clustered a } \\
\text { effects consider a fixe } \\
\text { and } * * * \text { denote signifi }\end{array}$ & $\begin{array}{l}\text { able } 5 \text { repor } \\
\text { for the base } \\
\text { alidation tes } \\
\text { the countr } \\
\text { effect for e } \\
\text { cance at } 10 \%\end{array}$ & $\begin{array}{l}\text { alidation test } \\
\text { e results witl } \\
\text { or the baselin } \\
\text { ndustry level } \\
\text { entity in our } \\
\% \text {, and } 1 \% \text { le }\end{array}$ & $\begin{array}{l}\text { s that evalu } \\
\text { equation ( } \\
\text { e conformir } \\
\text {, with indus } \\
\text { r sample. W } \\
\text { evels, respec }\end{array}$ & $\begin{array}{l}\text { the role of in } \\
\text { Columns (5) a } \\
\text { ax avoidance } \\
\text { based on one } \\
\text { ovide variable } \\
\text { ly. }\end{array}$ & $\begin{array}{l}\text { national inco } \\
\text { (6) of Table } \\
\text { alysis. The s } \\
\text { igit SIC cod } \\
\text { efinitions in }\end{array}$ & $\begin{array}{l}\text { shifting as an } \\
\text { port estimates } \\
\text { ard errors are } \\
\text { he firm fixec } \\
\text { ndix 1. *, ** }\end{array}$ \\
\hline
\end{tabular}


Table 6: Validation tests: Impact of the German BTR 2008 on provisions

\begin{tabular}{|c|c|c|c|}
\hline Dependent variable & & Log Provisio & \\
\hline Sample & $\begin{array}{l}\text { All } \\
\text { (1) }\end{array}$ & $\begin{array}{l}\text { Domestic } \\
\text { (2) }\end{array}$ & $\begin{array}{c}\text { MNE } \\
\text { (3) }\end{array}$ \\
\hline Treat $\times$ TPeriod & $\begin{array}{c}-0.210 * * * \\
(-9.951)\end{array}$ & $\begin{array}{c}-0.114 * * * \\
(-2.797)\end{array}$ & $\begin{array}{c}-0.243 * * * * \\
(-9.902)\end{array}$ \\
\hline Log Assets & $\begin{array}{c}0.433 * * * \\
(18.374)\end{array}$ & $\begin{array}{c}0.565^{* * *} \\
(12.819)\end{array}$ & $\begin{array}{c}0.398 * * * \\
(14.510)\end{array}$ \\
\hline Log Compensation & $\begin{array}{c}0.322 * * * \\
(13.922)\end{array}$ & $\begin{array}{c}0.258 * * * \\
(6.952)\end{array}$ & $\begin{array}{c}0.344 * * * \\
(11.988)\end{array}$ \\
\hline $\log G D P$ & $\begin{array}{c}-1.242 * * \\
(-2.093)\end{array}$ & $\begin{array}{c}1.027 \\
(0.902)\end{array}$ & $\begin{array}{c}-2.209 * * * * \\
(-3.161)\end{array}$ \\
\hline Log GDP per capita & $\begin{array}{c}1.463 * * * \\
(2.974)\end{array}$ & $\begin{array}{c}-0.089 \\
(-0.091)\end{array}$ & $\begin{array}{c}2.167 * * * \\
(3.788)\end{array}$ \\
\hline Firm fixed effects & $\sqrt{ }$ & $\sqrt{ }$ & $\sqrt{ }$ \\
\hline Year fixed effects & $\sqrt{ }$ & $\sqrt{ }$ & $\sqrt{ }$ \\
\hline Observations & 81,493 & 24,211 & 57,282 \\
\hline Number of firms & 21,912 & 7,298 & 14,614 \\
\hline $\mathrm{R}^{2}$ & 0.937 & 0.926 & 0.937 \\
\hline
\end{tabular}

Table 6 reports coefficient estimates and t statistics (in parentheses) for our validation test on the impact of the German BTR of 2008 on provisions with equation (3). The standard errors are robust and clustered at the group level, with group based on the global ultimate owner (GUO). The firm fixed effects consider a fixed effect for each entity in our sample. We provide variable definitions in Appendix 1. *,**, and *** denote significance at $10 \%$, $5 \%$, and $1 \%$ levels, respectively. 
Table 7: Cross-sectional tests on book-tax conformity

\begin{tabular}{|c|c|c|c|c|c|c|}
\hline \multirow{3}{*}{$\begin{array}{l}\text { Dependent Variable } \\
\text { BTaxC Measure } \\
\text { Sample } \\
\text { Model }\end{array}$} & \multicolumn{6}{|c|}{$\log P T I$} \\
\hline & \multicolumn{3}{|c|}{ Watrin/Ebert/Thomsen (2014) } & \multicolumn{3}{|c|}{ Tang (2015) } \\
\hline & $\begin{array}{l}\text { All } \\
\text { (1) }\end{array}$ & $\begin{array}{c}\text { Domestic } \\
\text { (2) }\end{array}$ & $\begin{array}{c}\text { MNE } \\
\text { (3) }\end{array}$ & $\begin{array}{l}\text { All } \\
\text { (4) }\end{array}$ & $\begin{array}{c}\text { Domestic } \\
(5)\end{array}$ & $\begin{array}{c}\text { MNE } \\
\text { (6) }\end{array}$ \\
\hline Tax Rate $\times$ BTaxC High & $\begin{array}{c}-0.936 * * * \\
(-3.563)\end{array}$ & $\begin{array}{c}-0.880 * * * \\
(-2.729)\end{array}$ & $\begin{array}{c}-0.857 * * \\
(-2.547)\end{array}$ & $\begin{array}{c}-1.424 * * * \\
(-3.159)\end{array}$ & $\begin{array}{c}-2.163 * * * \\
(-3.612)\end{array}$ & $\begin{array}{l}-0.835 * \\
(-1.792)\end{array}$ \\
\hline Tax Rate & $\begin{array}{c}-1.713 * * * \\
(-5.709)\end{array}$ & $\begin{array}{c}-1.332 * * * \\
(-3.690)\end{array}$ & $\begin{array}{c}-2.418 * * * \\
(-6.496)\end{array}$ & $\begin{array}{c}-3.609 * * * \\
(-14.459)\end{array}$ & $\begin{array}{c}-3.710 * * * \\
(-11.805)\end{array}$ & $\begin{array}{c}-3.728 * * * \\
(-14.340)\end{array}$ \\
\hline BTaxC High & $\begin{array}{c}-0.013 \\
(-0.173)\end{array}$ & $\begin{array}{c}-0.118 \\
(-1.269)\end{array}$ & $\begin{array}{c}0.049 \\
(0.530)\end{array}$ & $\begin{array}{c}0.323^{* *} \\
(2.203)\end{array}$ & $\begin{array}{c}0.524 * * * \\
(2.752)\end{array}$ & $\begin{array}{c}0.127 \\
(0.850)\end{array}$ \\
\hline Log Assets & $\begin{array}{l}0.769 * * * \\
(108.853)\end{array}$ & $\begin{array}{c}0.761 * * * \\
(70.455)\end{array}$ & $\begin{array}{c}0.752 * * * \\
(93.852)\end{array}$ & $\begin{array}{l}0.763 * * * \\
(104.667)\end{array}$ & $\begin{array}{c}0.754 * * * \\
(70.553)\end{array}$ & $\begin{array}{c}0.747 * * * \\
(89.716)\end{array}$ \\
\hline Log Compensation & $\begin{array}{l}0.168 * * * \\
(25.159)\end{array}$ & $\begin{array}{c}0.144 * * * \\
(16.460)\end{array}$ & $\begin{array}{c}0.188 * * * \\
(24.272)\end{array}$ & $\begin{array}{c}0.180 * * * \\
(26.060)\end{array}$ & $\begin{array}{c}0.156^{* * * *} \\
(17.592)\end{array}$ & $\begin{array}{c}0.195 * * * \\
(24.415)\end{array}$ \\
\hline $\log G D P$ & $\begin{array}{c}-0.034 * * * \\
(-3.389)\end{array}$ & $\begin{array}{c}-0.067 * * * \\
(-5.182)\end{array}$ & $\begin{array}{c}0.003 \\
(0.253)\end{array}$ & $\begin{array}{c}0.052 * * * \\
(4.351)\end{array}$ & $\begin{array}{c}0.058^{* * * *} \\
(3.993)\end{array}$ & $\begin{array}{c}0.052 * * * \\
(3.856)\end{array}$ \\
\hline Log GDP per Capita & $\begin{array}{c}0.189 * * * \\
(8.593)\end{array}$ & $\begin{array}{c}0.184 * * * \\
(6.896)\end{array}$ & $\begin{array}{c}0.223 * * * \\
(8.202)\end{array}$ & $\begin{array}{c}0.299 * * * \\
(7.251)\end{array}$ & $\begin{array}{c}0.385^{* * * *} \\
(7.520)\end{array}$ & $\begin{array}{c}0.258 * * * \\
(6.032)\end{array}$ \\
\hline Parent & $\begin{array}{c}-0.207 * * * \\
(-15.436)\end{array}$ & $\begin{array}{c}-0.176 * * * \\
(-10.832)\end{array}$ & $\begin{array}{c}-0.163 * * * \\
(-7.279)\end{array}$ & $\begin{array}{c}-0.181 * * * \\
(-12.759)\end{array}$ & $\begin{array}{c}-0.116 * * * \\
(-6.609)\end{array}$ & $\begin{array}{c}-0.157 * * * \\
(-7.006)\end{array}$ \\
\hline Public & $\begin{array}{c}0.197 * * * \\
(13.276)\end{array}$ & $\begin{array}{c}-0.081 \\
(-0.911)\end{array}$ & $\begin{array}{c}0.144 * * * \\
(9.574)\end{array}$ & $\begin{array}{c}0.216^{* * * *} \\
(14.495)\end{array}$ & $\begin{array}{c}-0.056 \\
(-0.680)\end{array}$ & $\begin{array}{c}0.149 * * * \\
(10.066)\end{array}$ \\
\hline Industry fixed effects & $\sqrt{ }$ & $\sqrt{ }$ & $\sqrt{ }$ & $\sqrt{ }$ & $\sqrt{ }$ & $\sqrt{ }$ \\
\hline Year fixed effects & $\sqrt{ }$ & $\sqrt{ }$ & $\sqrt{ }$ & $\sqrt{ }$ & $\sqrt{ }$ & $\sqrt{ }$ \\
\hline Observations & 426,593 & 211,897 & 214,696 & 420,827 & 210,411 & 210,416 \\
\hline Number of firms & 104,031 & 53,284 & 50,747 & 102,818 & 52,940 & 49,878 \\
\hline $\mathrm{R}^{2}$ & 0.603 & 0.448 & 0.625 & 0.602 & 0.444 & 0.625 \\
\hline
\end{tabular}

Table 7 reports coefficient estimates and t statistics (in parentheses) for our tests of the association between booktax conformity and conforming tax avoidance (H1) with equation (4). The standard errors are robust and clustered at the country-industry level, with industry based on one-digit SIC codes. We provide variable definitions in Appendix $1 . *, *$, and $* * *$ denote significance at $10 \%, 5 \%$, and $1 \%$ levels, respectively. 
Table 8: Changes in book-tax conformity

\begin{tabular}{|c|c|c|c|c|c|c|}
\hline Dependent Variable & & & Log & PTI & & \\
\hline BTaxC Measure & Watrin/E & ert/Thomse & (2014) & & Tang (2015 & \\
\hline Sample & All & Domestic & MNE & All & Domestic & MNE \\
\hline Model & (4) & (5) & (6) & (4) & (5) & (6) \\
\hline Tax Rate $\times$ BTaxC Change & $-0.347 * * *$ & $-0.474 * * *$ & $-0.195 * *$ & $-0.442 * * *$ & $-0.567 * * *$ & $-0.366 * *$ \\
\hline & $(-3.890)$ & $(-4.104)$ & $(-2.196)$ & $(-3.367)$ & $(-3.267)$ & $(-2.411)$ \\
\hline Tax Rate & $-0.992 * * *$ & $-1.224 * * *$ & $-0.800 * * *$ & $-0.831 * * *$ & $-0.957 * * *$ & $-0.736 * *$ \\
\hline & $(-3.883)$ & $(-3.726)$ & $(-2.764)$ & $(-3.119)$ & $(-2.861)$ & $(-2.385)$ \\
\hline BTaxC Change & $0.097 * * *$ & $0.138 * * *$ & $0.051 * *$ & $0.129 * * *$ & $0.171 * * *$ & $0.099 * *$ \\
\hline & $(3.747)$ & $(4.094)$ & (2.084) & $(3.055)$ & $(3.072)$ & $(2.021)$ \\
\hline Log Assets & $0.714 * * *$ & $0.760 * * *$ & $0.675^{* * *}$ & $0.712 * * *$ & $0.759 * * *$ & $0.669 * * *$ \\
\hline & $(55.270)$ & $(33.996)$ & $(46.637)$ & $(54.091)$ & $(33.644)$ & $(45.491)$ \\
\hline Log Compensation & $0.158 * * *$ & $0.117 * * *$ & $0.207 * * *$ & $0.154 * * *$ & $0.112 * * *$ & $0.205^{* * *}$ \\
\hline & $(14.665)$ & $(9.032)$ & (15.109) & $(14.286)$ & (8.698) & $(14.640)$ \\
\hline $\log G D P$ & $2.087 * * *$ & $3.791 * * *$ & $1.174 * *$ & $1.507 * * *$ & $2.839 * * *$ & 0.890 \\
\hline & $(4.273)$ & $(5.784)$ & (2.126) & $(3.055)$ & $(4.541)$ & (1.530) \\
\hline Log GDP per Capita & $-2.085 * * *$ & $-3.525^{* * *}$ & $-1.386^{* *}$ & $-1.489 * * *$ & $-2.573^{* * *}$ & $-1.088^{*}$ \\
\hline & $(-4.194)$ & $(-5.336)$ & $(-2.542)$ & $(-2.956)$ & $(-4.070)$ & $(-1.885)$ \\
\hline Firm fixed effects & $\sqrt{ }$ & $\sqrt{ }$ & $\sqrt{ }$ & $\sqrt{ }$ & $\sqrt{ }$ & $\sqrt{ }$ \\
\hline Year fixed effects & $\sqrt{ }$ & $\sqrt{ }$ & $\sqrt{ }$ & $\sqrt{ }$ & $\sqrt{ }$ & $\sqrt{ }$ \\
\hline Observations & 380,200 & 188,378 & 191,822 & 375,262 & 188,482 & 186,780 \\
\hline Number of firms & 99,376 & 50,445 & 48,931 & 98,890 & 50,968 & 47,922 \\
\hline $\mathrm{R}^{2}$ & 0.855 & 0.796 & 0.865 & 0.857 & 0.797 & 0.866 \\
\hline
\end{tabular}

Table 8 reports coefficient estimates and t statistics (in parentheses) for our tests of the association between booktax conformity and conforming tax avoidance (H1) with equation (5). The standard errors are robust and clustered at the country-industry level, with industry based on one-digit SIC codes. The firm fixed effects consider a fixed effect for each entity in our sample. We provide variable definitions in Appendix 1. *, **, and *** denote significance at $10 \%, 5 \%$, and $1 \%$ levels, respectively. 